\title{
METODA DE SĂPĂTURĂ ŞI ÎNREGISTRAREA DATELOR STRATIGRAFICE ÎNTR-UN SIT PLURISTRATIFICAT: TELL-UL NEO-ENEOLITIC DE LA HÎRSOVA
}

Bernard Randoin ${ }^{1}$

Dragomir Popovici ${ }^{2}$

Yannick Rialland ${ }^{3}$

\begin{abstract}
Această scurtă prezentare a concepției, metodei precum şi a tehnicilor de săpătură utilizate pe tell-ul de la Hârşova nu-şi propune să detalieze in extenso tot ceea ce se desfáşoară aici, ea încercând să traseze doar aspectele pe care le-am considerat a fi cele mai importante şi mai relevante pentru cei interesaţi. Pentru a nu fragmentà prea mult textul nostru am fost uneori obligaţi să menţionăm sau să repetăm aspecte care, desigur, sunt foarte cunoscute ariheologilor români sau care sunt utilizate, folosite de mult timp în arheologia românească.
\end{abstract}

De la sfârsitul anilor '60 si până la începutul anilor ' 90 , Europa de vest a cunoscut un mare curent de restructurare a centrelor vechi ale oraselor istorice, fie că era cazul teconstruirii vechilor cartiere devenite insalubre, fie că se punea problema construirii unor monumente publice. Aceste lucrări, erau adesea însotite de realizarea unor parcări subterane care au antrenat la rândul lor nasive distrugeri ale vegtigiilor sau a nivelurilor arheologice. A apărut astfel pericolul disparitiei rapide a informatiilor arheologice si istorice, esentiale pentru întelegerea genezei si evolutiei marilor centre urbane şi în consecinţă au trebuit să fie adaptate metodele si tehnicile de cercetare a acestor sit-uri întotdeauna complexe. În aceste conditii s-a dezvoltat în tot nordul Europei, începând din anii '60 o nouă disciplină arheologică si noi tehnici.

Asezările urbane prezintă două constante principale: în principal, ele oferă secvente de ocupaţie neîntrerupte de-a lungul a mai multe secole (cel mai adesea începând cu epoca romană şi continuând până în zilele noastre), ceea ce se concretizează printr-o stratificare abundentă în care depozitul arheologic poate atinge grosimi cuprinse între 4 si $10 \mathrm{~m}$. Apoi, această stratificare este, de regulă, complicată de suprapunerea diferitelor faze ocupaţionale, a unor multe şi variate construcţii ca şi distrugerile sau modificările pe care acestea le-au suferit de-a lungul timpului.

În aceste condiți este evident că a fost necesară utilizarea unor tehnici care să asigure o cât mai bună lectură a acestor informaţii stratigrafice şi mai mult decât atât, înregistrarea cât mai exhaustivă a acestora.

Dar, în momentul în care arheologul a avut la dispoziţie tehnicile de teren cele mai adecvate, s-a văzut în fata unei mase documentare impresiohante, atât datorită cantităţii, diversităţii (informaţii referitoare la stratigrafie, inventar şi structură), cât şi complexităţii sale. Una din marile dificultăţi ale arheologiei urbane rezidă deci atât în exploatarea sistematică a acestei mase documentare cât şi în realizarea unei săpături de cât mai bună calitate. Acest demers de teren trebuie în consecinţă completat de tehnici raţionale care să permită la rândul lor o exploatare optimală a acestor informaţii.

\footnotetext{
${ }^{1}$ Ministerul Culturii şi Comunicaţiei, Direcţia de Arhitectură şi Patrimoniu, Serviciul Arheologie, Paris.

${ }^{2}$ Muzeul Naţional de Istorie a Romániei, Bucureşti.

${ }^{3}$ Centrul Afacerilor Culturale, Direcţia regională, Serviciul regional de Arheologie, Clermond Ferrand.
} 
Acestor imperative li se adauga o serie de constrângeri impuse de necesitatea realizării unor cercetări de mare anvergură, care, numai ele, permit o bună întelegere a evoluției unui oraş şi care nu pot fi realizate decât de către o echipă în cadrul căreia fiecare membru are o responsabilitate precisă în cadrul cercetării ce urmează a fi efectuată (săpătura propriu-zisă, exploatarea datelor stratigrafice, gestionarea inventarului, studiul specific al acestuia etc.). Dacă participarea mai muitor cercetători specializaţi este singura modalitate ce permite o exploatare rapidă şi sistematică a rezultatelor, în aceste condiţll se impune utilizarea unui sistem global ce vizează coordonarea cercetării şi permite utilizaree în comun a datelor.

În cursul primelor contacte dintre arheologii români din cadrul Muzeului National de Istorie a României şi arheologii francezi din regiunea Centre pe siturile din Orleans, Blois şi în primul rînd Chartres, a fost evident faptul că stratificarea unui sit urban şi cea a unui tell neolitic prezintă mari similitudini. Şi într-un caz şi în celălalt ne găsim în faţa unor acumulări constituite într-un singur loc şi care constau din vestigii ale unor locuiri de-a lungul unui interval de timp lung şi deci din suprapunerea unor multiple construcţii. Plecându-se de la această constatare s-a născut ideea de a încerca aplicarea în cazul tell-ului neolitic de la Hârşova a metodelor de săpătură şi inregistrare inspirate din cele utilizate în cazul săpăturilor în mediu urban, evident, ţinându-se cont de specificităţile stratificării dintr-un tell şi de problematica particulară a studiului comunităţilor neolitice.

Ne propunem în cele ce urmează să prezentăm tehnicile de săpătură şi înregistrare care au servit drept model pentru œele utilizate la Hîrşova, utilizate începând din 1974 la Tours şi care s-au răspândit, puţin câte puţin în ansamblul sit-urilor urbane din regiunea Centre, apoi şi în numeroase alte regiuni ale Frantei. A fost evident faptul, vizibil în timpul colocviului organizat în 1987 la Tours, cu tema "Înregistrarea datelor în cazul săpăturilor în mediu urban" (Enregistrement des donnees de fouilles urbaines, Randoin, 1987) că cea mai mare parte a echipelor utilizau tehnici bazate pe aceleaşi principii, ele diferind numai din punctul de vedere al fişelor sau al vocabularului utilizat.

\section{SĂPĂTURA ŞI ÎNREGISTRAREA DATELOR STRATIGRAFICE}

În Anglia, la Winchester, odată cu realizarea unui vast program de cercetări arheologice a oraşlui s-au pus cu acuitate problemele la care dorim să ne referim în cele ce urmează. Săpăturile conduse de către Martin Biddle în acest scop l-au condus prin intermediul importanţei şi mai ales prin complexitatea lor, la punerea la punct a acestei tehnici în cazul sit-ului Wolvesey Palace. Începând din 1974 această metodă a fost folosită la Tours unde perfectionarea sa a fost continuată cu scopul de a asigura o înregistrare mai bună a datelor stratigrafice.

Ne vom limita deci la acest aspect încercâno să examinăm modalitătile de înregistrare a datelor stratigrafice în cazul sit-urilor urbane şi a tehnicilor de exploatare a acestor date cu scopul de a ajunge la nivelul ce permite reconstituirea sitului ca şi modifir.ările aduse sistemului în scopul adaptării acestuia la studiul tell-ului.

\section{SĂPĂTURA}

Nu este în intenţia noastră de a propune o metodă de săpătură cu valoare universală şi nici de a da un număr de reţete care să asigure reuşita în cazul unei săpături într-un sit pluristratificat. Ne apropiem mai mult de convingerea conform căreia metoda de cercetare şi tratare a unui sit trebuie să 
permită o cât mai bună modalitate de reconstituire a istoriei sale. Pentru aceasta, fiecare sit supus unei cercatări arheologice trebuie studiat în cele mai mici detalii pentru a se putea defini transformările pe care le-a suferit de-a lungul timpului, de a se stabili ordinea în care aceste transformări s-au succedat şi cauzele care le-au determinat. Dacă în principiu ne putem declara satisfăcuţi de întelegerea schematică a stratificării unui sit simplu, cunoaşterea, înţelegerea stratigrafiei unui sit pluristratificat necesită o tehnică mult mai fină, deoarece succesiunea structurilor construite ca şi remanierile ce pot apărea în consecinţ̆ fac dificilă atribuirea pe moment a fiecărui element al unei faze precise dia evoluţia sit-ului. Reconstituirea istoriei acestuia trece deci prin identificarea fiecărei unităţi stratigrafice ce-l compune.

\section{Unitatea stratigrafică}

Trebuie să ne oprim aici asupra acestui termen anodị al vocabularului arheologic şi să examinăm realităţile pe care el le acoperă. Într-adevăr, nu există termen mai mult utilizat de către arheologi ca acela de unitate stratigrafică (U.S.), strat sau chiar de context şi care adesea a servit pentru desemnarea unor realităţi diferite şi care corespund, acestea două din urmă, (în terminologia noastră) unor ansambluri mai largi (secvenţă, fază sau perioadă) pe care le vom defini în cele ce urmează. Termenul de unitate stratigrafică va fi utilizat pentru a defini cea mai mică unitate stratigrafică vizibilă cu ochiul : este atomul arheologic.

Este bineânţeles loc comun, afirmarea faptului că solul se înalţă prin acumularea sedimentului natural sau produs de activitatea umană, dar trebuie să adăugăm că fiecare tip de activitate umană produce un sediment a cărui natură variază în functie de specificul acesteia. De exemplu, unităţlle stratigrafice formate într-o locuinţă de către ocupanţii săi vor fi foarte diferite de cele pe care le vom găsi în nivelurile de construcţie.

Atunci când remarcăm, pe teren, variaţii de culoare sau de textură, ne putem întreba dacă această variaţie nu reprezintă o schimbare în cadrul activitătii care s-a desfaşurat în asezare, chiar dacă, uneori nu putem percepe imediat toate implicaţiile. Fiecare dintre aceste sedimente pe care le considerăm aici drept unităţi stratigrafice şi identificarea lor o cere, pe lângă o bună experienţă de teren, executarea unei săpături curate şi controlate, care numai ea singură asigură vizualizarea şi întelegerea tuturor variaţiilor de sol. O "disecţie" atât de precisă a sitului, mult timp a determinat surâsuri, đar este evident că ea este singura care să garanteze o bună întelegere a stratigrafiei. Dacă este totıjeauna posibil, datorită excesului de precauţie, să fie regrupate incorect două uniţ̆ţi stratigrafice, nu este mai puţin adevărat că nu vom putea niciodată separa mobilierul din două unităţi stratigrafice care nu au fost imediat separate una de cealaltă. Putem deci, în consecinţă să afirmăm că prima regulă ce trebule respectată pe teren constă în identificarea fiecărei unităţi stratigrafice.

Pentru reconstituirea evenirnenţială a unui sit, nu este suficientă individualizarea acestor elemente, ci trebuie determinată, de asemeni, ordinea în care aceste elemente s-au format şi deci au apărut, adică ceea ce sir Mortimer Wheełer definea a fi drept "primary duty" a arheologului (Wheeler, 1956, 56), stabilirea relatiilor de posterioritate şi anterioritate existente între diferitele unităţi stratigrafice conform principiului stratigrafiei. Determinarea acestora, acompaniată de colectarea separată a mobilierului și steoilirea cronologiei lor relative prin intermediul stuoiului relaţilior stratigrafice, sunt cele două imperative fără de care nici o săpătură cu valoare stiinţifică nu este posibila. 
Acestor două principii fundamentale trebuie să le adăugăm un al treilea care constă din interpretarea arheologică a unităţilor stratigrafice. Ea permite înțelegerea procesului, fenomenului sau aç̧iunii umane în urma cărora un anumit depozit s-a format pe sit în momentul respectiv.

Această interpretare trebuie stabilită cât mai precis posibil: ea se bazează pe înseşi natura unităţii stratigrafice şi pe natura elementelor sale constitutive, înclinare, localizare în cadrul situtui, fiind în cele din urmă rezultatul unui prim nivel al reflexiei arheologice. Trebuie să adăugăm aici unul din principalele pericale pe care le prezintă o astfel de tehnică de săpătură necesitând o atât de minuţioasă analiză a siturilor pluristratificate, acel "watch-maker's job" menţionat de Sir Mortimer Wheeler şi care constă în principal în a considera analiza stratigrafică detaliată şi înregistrarea sa exhaustivă ca fiind suficient de obiectivă pentru a nu mai avea de nimic altceva nevoie. Aceasta poate conduce spre o aplicare rutinieră a unei tehnici care abtfel devine mecanică si care nu va permite altceva decât colectarea si înregistrarea datelor pretins obiective si care nu vor putea fi exploatate ulterior. Căci, indiferent care ar fi metoda sau tehnica aleasă pentru a analiza si interpreta informatia arheologică dintr-o asezare, nu va fi posibil, în cel mai bun caz, decât să se poată preciza şi verifica ipotezele formulate în timpul săpăturii, dar ea nu va permite niciodată realizarea unui raţionament arheologic bazat pe nimic.

Din acest punct de vedere, trebuie să subliniem o derivă potentială a acestui sistem foarte"strâns", derivă pe care multe echipe ce I-au utilizat au cunoscut-o şi care constă din atribuirea de multe numere de unități stratigrafice cu scopul de a se înregistra orice element stratigrafic (unitate stratigrafică, structură, aliniament de pietre... etc.), pe care arheologul doreste să-I individualizeze pentru-că el pare într-un moment sau altul al săpăturii, aparent important, fără însă să-i înteleagă nici poziţia stratigrafică nici funcţionalitatea. Înregistrarea acestor elemente face apel atunci la sisteme de fişe extrem ide elaborate, completate de desene sistematice. Dacă nu suntem atenti, această iluzie de obiectivitate, care conferă săpăturii un aşa-zis statut stiinţific, tinde să înlocuiască reflexia deoarece se dispune de un desen precis pe seama căruia se atribuie în mod eronat întelegerea a ceea ce nu s-a putut înţelege pe teren. Experienţa a demonstrat că ceea ce nu este înteles pe teren (natura, funcţia şi poziţia stratigrafică), nu va putea fi înţeles ulterior decât în foarte puţine cazuri.

În consecinţă, înregistrarea stratigrafică nu trebuie niciodată să încurajeze "lenea" intelectuală şi trebuie să nu se uite că săparea unei uniţăti stratigrafice constitue în sine un moment privilegiat care trebuie să permită reflexia arheologică ce mai târziu va fi foarte greu de realizat în condiţiile în care aceasta a fost săpată. Un sit nu va putea fi interpretat decât dacă rie luăm precauł̧la de a ịdentifica unităţile stratigrafice, de a stabili relaţiile lor stratigrafice şi de a defini cauzele care au condus la formarea lor.

\section{Subdivizarea sit-ului}

Pantru a asiguria o bună nealizare a acestor operatiuoi elementare, suprafată ce urmează a fi săpată va fi divizată în mai multe suprafete, fiecare dintre acestea fiind plasată sub conducerea unui membru al echipei care trebuie să supravegheze săpătura si să efectueze înregistrările. Desigur că desemnerea fiecărui responsabil trebuie făcută în functie de competenţa dictată de întelegerea metodei în primul rând. Suprafaţa acestora poate fi definită în funcţie de mai multe criterii determinate de complexitatea stratificării, nivelul competenței responsabilului sau de configuraţia specifică a săpăturii (suprafată, formă, etc.). Această divizare a sit-ului faciliteazł̆ controlul săpăturii dar ea nu este suficientă în sine pentru a satisface în cele mai bune conditii înregistrarea stratigrafică şi în 
consecinţă se impune în acelaşi timp subdivizarea suprafeței cercetate prin intermediul unor profile stratigrafice.

La Hîrşova existând de la începutul săpăturii un caroiaj compus din module de $2 \times 2 \mathrm{~m}$, suprafaţa b a fost divizată în sectoare rectangulare, cu latura de $6 \times 6 \mathrm{~m}$ care au permis astfel integrarea vechiului sistem de referinţe. desigur, ţinând cont de forma terenului ca şi de imposibilitatea de a se modifica suprafaţa săpată, nu toate sectoarele au avut aceeaşi suprafaţă.

La acest nivel, ni se pare iluzoriu să propunem un sistem rigid deoarece fiecare sit şi chiar fiecare zonă pot impune constrângeri diferite. Adesea este imposibil dacă nu chiar periculos de a impune un caroiaj de $4 \times 4$ m după cum preconiza Sir Mortimer Wheeler. Ceea ce ni se pare evident este faptul că săpătura a trebuit să fie adaptată condiţiilor concrete în care, astfel cum adeseori ea este obligată să se desfăşoare. În multe cazuri arheologul este obligat să dea forme neregulate săpăturii sale. În această situaţie problema care se pune, logic, a constat în amplasarea profilelor strattigrafice, în condiţiile în care este evident faptul că aceasta trebuia realizată astfel încât să asigure cea mai bună (posibil), înregistrare a stratigrafiei existente, desigur perpendiculară pe posibilele structuri existente sau presupuse. (clădiri, străzi, zone de pasaj, etc.).

Frecvenţa acestor profile stratigrafice este determinată de către tipul de stratificare. Astfel, s-a ţinut cont de faptul că în cazul anui sit cu o stratigrafie simplă se putea uțiliza o grilă relativ largă, în timp ce în cazul unei stratigrafii mai complexe, cum era cazul tell-ului se recomandă utilizarea unei grile de secţiuni stratigrafice mai dese, bineânţeles dispuse riguros ortogonal, concretizate în teren prin martorii stratigrafici.

\section{Săpătura orizontală, săpătura verticală}

Este desigur, dificil, atunci când discutăm despre tehnica de săpătură şi abordăm capitolul martorilor şi acela al stratigrafiei, să nu menţionăm polemica dintre partizanii martorilor largi de $1 \mathrm{~m}$ care trebuie să delimiteze carourile în care este împărţită săpătura conform sistemului definit de către Sir Mortimer Wheeler şi partizanii utilizării unor martori mai înguşti.

Problema ar fi fost simplă dacă nu ar fi fost decât o chestiune de centimetri ai suprafetei săpate sau nu, dar în fapt se pune problema utilizării diferite a profilelor stratigrafice şi mai ales de manifestarea a două filosofii a săpăturii care tind, una, de a privilegia săpătura verticală, păstrând martorii până la sfârş̧itul săpăturii, cealaltă, de a realiza o săpătură orizontală care ar permite expunerea nivelurilor contemporane pe totalitatea sit-ului, situaţie în care se impune demontarea periodică a martorilor.

Antagonismul dintre aceste două şcoli se bazează de fapt pe natura cercetărilor realizate, fiind înveninat în consecință de o altă neînțelegere: într-adevăr, Sir Mortimer Wheeler nu preconiza menţinerea sistematică a martorilor până la nivelul în care aceştia puteau deveni o constrângere a săpăturii şi deci am putea căuta în van în vre-una din lucrările sale vre-o interdicţie formală referitoare la săparea lor. Dimpotrivă, el considera că în anumite situaţii aceşti martiori puteau fi demontaţi: "...so that ultimately the barriers between the square can be removed without loss of vertical evidence and the whole plan laid bare, level by level" (Wheeler, 1958, 83).

O neîntelegere asemănătoare este cauza ce a generat tehnicile de săpătură preponderent orizontale şi care nu utilizează decât în situaţii cu totul excepţionale profilele stratigrafice. Această 
caricatură de sistem, numit "open area" este, fără îndoială născută dintr-o proastă întelegere a metodei.

Într-adevăr, dacă încercăm să reconstituim această tehnică pe baza publicării rezultatelor, nu vom avea la dispozitie decât fotografii sau planuri ce aratå suprafeţe întinse în care nu există nici un semn al existentei vre-unui martor stratigrafic, deoarece aceste ilustrab̧i prezintă un moment din evoluţia săpării sit-ului respectiv, realizat evident după demontarea martorilor (Biddle, 1972, U). În cazul săpăturilor urbane sau în cazul sit-urilor pluristratificate, utilizarea mertorilor înguşti depinde numai de natura stratificării. S-a putut observa, de exemplu, existenţa a numeroase modificări stratigrafice între două puncte depărtate nu mai mult de câteva zeci de centimetri şi experienţa a demonstrat că martorii clasici, cu lătimea de $1 \mathrm{~m}$. , pot împiedica considerabil înţelegerea săpăturii. Dar, în acelaşi timp, utilizarea martorilor largi s-a dovedit a fi utilă şi chiar necesară în cazul situaţiilor în care se dorea conservarea mai mult timp a profilelor stratigrafice sau în cazul în care terenul în care se efectuează săpătura prezenta o slabă coeziune. În cele ce urmează vom aborda problema examinării rolului pe care îl joacă martorii în cadrul acestei metode şi maniera în care se pot utiliza profilele stratigrafice.

Tot Sir Mortimer este cel ce poate lămuri această dezbatere, prin intermediul uneia dintre metaforele care î împodobesc scrierile. Astfel, după ce aminteste că stratigrafia este datoria primordială a arheologului, el scrie: "Vertical excavation alone...is the railway time without a train. On the other hand, the extension hotizontal excavations...were trains without a time table".

Este cazul aici de existenţa a două tehnici complementare şi nu aritinomice. Se poate admite deci practicarea unei săpături cu caracter de sondaj, al cărei scop principal este de a stabili stratigrafia şi eventual cronologia unui sit, concepută ca fază pregătitoare a unei săpături mai ample, ulterioare şi care deci, în aceste condiţii poate fi executată într-o manieră strict verticală. Dar, atunci când este cazul unei săpături ample, programată pe o mai lungă durată şi pe o suprafaţă mai mare, este de neacceptat necombinarea metodei verticale cu cea orizontală, care se constitue în singura modalitate ce poate permite caracterizarea naturii locuirii respective şi reconstituirea mediului ambiant imediat. Pentru a putea avea succes, o asemenea metodă implică cercetarea unei suprafeţe cât mai mari, asupra căreia trebuie exercitat un control cât mai strict posibil. Ori, acesta nu poate fi realizàt decât numai prin intermediul operaţiunilor mecanice de săpare şi înregistrare a unităţilor stratigrafice în relaţie cu o reflexie arheologică aprofundată, de natură să permită determinarea contemporaneităţii diverselor elemente constitutive ale structurilor surprinse în cursul săpăturii.

Tell-ul de la Hîrsova oferă din acest punct de vedere posibilităţi pe care nu le n̂tâlnim decât cu totul excepţionat în sit-urile urbane unde această metodă a fost imaginată : în principal aceea de a obtine informaţii care să parmită reconstituifea modului de viaţă a locuitorilor respectivi. Acest tip de demers, etnografic, asupra unui sit nu poate fi utilizat cu succes decât în cazul aşezărilor care nu au fost, sau foarte putin, perturbate ulterior abandonării şi a căror matrice, în cazul nostru loessul, conservă materialele perisabile și fosilizează rapid diversele soluri (pl.I/a). Astfel, devine posibila definirea, desigur şi prin desenare şi cotare altimetrică, a unor diferite zone de activităţi specifice (depozite, anexe, bucătării, ateliere, zone de pasaj, etc.). Această analiză a diverselor moduri de viată (mai precis a comportamentelor umane), presupune Implicarea directă a stilnţelor naturii în conditiile unui strict control stratigrafic care este esenţial pentru a asigura o maximă pertinenţă a eşantioanelor prelevate de către specialişti. Este evident că în acelasi timp, aceste condiţii pot asigura o maximă pertinenţă a problemelor puse de către arheolog celorlalţi specialiş̧t. 
În aceste condiţii este evident faptul că alegerea tehnicilor ce urmează a fi utilizate depinde de natura terenului, de abiectivele cercetării şi nu în ultimul rând de mijloacele existente la dispoziţie. Arheologia sit-urilor cu stratigrafie complexă trebuie să utilizeze metode care permit pe de o parte datarea precisă a diferitelor tipuri ocupaţionale a sit-ului supus studiului, dar pe de altă parte o întelegere cât mai completă posibil a tipurilor de ॥locuire şi a diferitelor activităţi ale căror urme pot fi "citite". Pentru a continua comparatia lui Sir Mortimer Wheeler, putem afirma că arheologul trebuie să dispună atât de tren dar şi de oraruf acestuia. Am subliniat faptul că aceste sit-uri ce comportă o stratigrafie complexă şi bogată, trebuio studiate de o manieră raţională şi minuţioasă, care să furnizeze o masă considerabilă de date documentare ce trebuie apoi înmagazinată şi utilizată.

\section{Tehnicile de înregistrare a datelor stratigrafice}

Prin însăşi natura ei săpătura implică distrugerea vestigiilor pe măsură ce ele sunt descoperite .Această afirmaţie a devenit de mult timp o banalitate, pe care nu socotim necesar să o mai repetăm. Cu toate acestea se pare că nu întotdeauna implicaţiile ce derivă din ea sunt percepute cu claritate.

În general este admisă necesitatea înregistrării "descoperirilor" dar credem că este nu lipsit de importanţă să ne purrem întrebarea de ce înregistrăm iar de aici cum realizăm aceasta. În consecinţă este evident faptul că trebuie să găsim maniera prin care să putem recupera ceea ce a fost distrus şi care în timpul săpării propriu-zise nu i s-a acordat suficientă atenţle. Deci trebuie realizat un sistem de înregistrare care să corespundă întrebărilor pe care le adresăm pe moment, sau de regulă ulterior, datelor.

În cazul studiului unui sit complex, problema care se pune de la bun început este aceea de a reconstitui istoria evenimenţială a fiecărei părţi constitutive, apoi de a asigura fiecărui element o datare cât mai precisă posibil şi în cele din urmă de a înţelege organizarea internă a tuturor acestora prin intermediul studiilor dirijate asupna resturilor materiale corespunzând fiecărei epoci.

\section{Înregistrarea unităţilor stratigrafice}

Bineânţeles că reconstituirea istoriei sit-ului se va baza pe înregistrarea stratigrafică, dar rolul său nu se limitează la acest singur aspect al reflexiei arheologice. Ea va servi de asemeni informării tuturor studiilor ce urmează a fi întreprinse asupra sit-ului (studiul inventarului propriu-zis, arheologic, dar şi pentru studiile asupra tehnicilor constructive, tipurilor de locuire, etc.).

Diversitatea şi amploarea informaţiilor pe care trebuie să le furnizeze acest sistem ca şi necesitatea utilizării unui colectiv adeseori numeros care trebuie să lucreze în acelaşi sit, impun o serie de constrângeri. De aceea el trebuie conceput de o manieră suficient de rigidă astfel încât, indiferent de personalitatea celui care a făcut înregistrarea, în condiţii de competenţă egală, acelaşi tip de informaţie să fie regăsit, astfel încât ea să fie accesibilă unui cercetător care nu a participat la săpătură.

În aceste condiţii este evident faptul că tot sistemul de înregistrare, aşa cum a fost el definit, se va baza pe unitatea stratigrafică. Astfel, cu scopul de a se elimina riscul de eroare şi de a se evita utilizarea referinţelor complexe ce ar putea include atât litere cât şi cifre, numerele de unităţi stratigrafice nu trebuie să poată fi confundate între zonele săpăturii. De aceea se alege pentru fiecare sector al acesteia câte o serie de câte 1000 numere. În consecinţă, sectorul 1 va cuprinde unităţi 
stratigrafice înregistrate de la 1 până la 999, sectorul 2 de la 1000 până la 1999, etc. Aceasta va permite înţelegerea rapidă şi regăsirea informaţiei ştiindu-se că, de exempłu, us.nr.1223 reprezintă o unitate stratigrafică descoperită, cercetată şi săpată în sectorul 2.

Pentru a se asigura coeziunea înregistrării unităţilor stratigrafice, la Hînşova noi am ales utilizarea unui sitem de fişe imprimate cate servesc în acelaşi timp la evitarea unei înregistrări defectuoase (omiterea anumitor elemente sau detalii, etc.) şi la o înregistrare rapidă şi implicit la o utilizare cât mai facilă. Đin aceleaşi motive, o pagină dublă de caiet va permite înregistrarea a trei unităţi stratigrafice, păstrându-se suficient spaţiu pentru fiecare dintre ele (pl. II/a,b).

Înainte de a examina realizarea propriu-zisă a acestei înregistrări a unităţilor stratigrafice, considerăm necesar să insistăm asupra manierei în care se desfăşoară operaţiunile în timpul săpăturii. Am menţionat faptul că suprafaţa ce urmează a fi săpată este divizată în sectoare delimitate de profilele stratigrafice materializate prin martorii stratigrafici. Unităţile stratigrafice urmează a fi săpate în interiorul acestor sectoare, una câte una. În funcţie de situaţia concretă din teren aceste sectoare nu pot fi întotdeauna săpate într-o ordine logică, aceasta depinzând de imperativele, scopurile cercetării, de nivelul experientei săpătorilor, sau de complexitatea anumitor situaţii. În aceste condiţii suntem obligeţi să tratăm fiecare sector drept o entitate independehtă, ceea ce va camplica înregistrarea. Aceasta va determina numerotarea fiecărei unităţi în cadrul fiecărui sector, deoarece nu întotdeauna este posibil să se poată determina relaţii fiabile între U.S.-urile din diferite sectoare sau corelaţii certe.

Fişele prezintă pe pagina din stânga numărui de înregistrare, urmat de două casete orizontale, separate de o linie. În momentul apariţiei unei unităţi stratigrafice, în caseta superioară va fi indicat numărul (sau numerele, în cazul în care sunt mai multe) de U.S.care a suprapus-o şi care este deci ulterioară. După ce aceasta a fost săpată, în caseta inferioară se va nota numărul de U.S. apărută (sau numerele de U.S. dacă sunt mai multe). Astfel vor fi înregistrate datele ce permit replasarea respectivei U.S. în contextul său stratigrafic.

Aceste relaţii pot ñ completate de o schemă stratigrafică sau un plan realizat pe caroiajul aflat pe pagina opusă. Apoi vor fi notate informatiile de ordin fizic, eventual ilustrate printr-o schiţă realizată rapid, de asemeni pe pagina din dreapta, la care se adaugă descrierea sa. Remarcăm că în cazul şantierului de la Hîrşova decizia a constat în a nu se face apel la nici o tehnică sofisticată de genul evaluare granulometrică sau referiri la vre-un cod de culoare care pretind din partea celui ce realizează înregistrarea o cantitate mare de timp şi care au fost o perioadă considerate drept elemente indispensabile pentru realizarea unei înregistrări obiective. În consecinţă noi am optat pentru o descriere care să se concentreze mai curând asupra elementelor constitutive determinante dintr-un punct de vedere în principal arheologic, decât geologic sau pedologic. Prezenţa sau absenţa cenuşii, a cărbunelui, a fragmentelor de chirpic ars sau nu, a fragmentelor de ceramică sau a oaselor le-am considerat drept informaţii mai utile şi oricum mai reprezentative pentru a putea caracteriza sedimentul respectiv şi implicit acţiunea umană ce l-a generat, decât referinţele reprezentate de cifre a căror precizie nu poate fi întotdeauna garantată.

Practic determinarea compozitiei flecărei U.S., efectuată înainte și după săparea ei poate permile definirea tipului de activitate care a generat-o. Această interpretare arheologică a fiecărei unităţi stratigrafice este capitală deoarece numai ea poate asigura o bună întelegere a sitului şi la acest nivel intervln cunostinţele de teren ale responsabilului de sector şi în general capacităţile sale. 
Activităţile care au generat unităţile stratigrafice pe care le întâlnim pe teren le-am grupat în trei mari tipuri : construcție, ocupaţie, distrugere, acestora noi adăugându-le, tinînd cont de situaţia de la Hîrşova alte trei: formaţie naturală, săpătură şi umplutură. Atribuirea fiecărei unităţi stratigrafice uneia dintre aceste tipuri de activităţi este notată într-o mică casetă rezervată interpretării arheologice. În cazul concret al tell-ului de aici nu este întotdeauna uşor ca prin intermediul examenului macroscopic să se poată determina cu certitudine dacă o unitate stratigrafică a fost formată în cursul unei actiuni de construcţie, distrugere sau nivelare în condiţiile în care ne găsim în prezenta unui acelasi tip de sediment loeossoid. În astfel de situaţii este indispensabil apelul la un examen mai aprofundat. În consecinţ̧ numeroase probe au fost prelevate în vederea realizării unor examene micromorfologice care în cele din urmă au permis o mai bună diferenţiere a U.S.-rilor respective. În condiţile în care dispunem de criterii fiabile, a fost posibilă diferenţierea rezultatelor unor activităti legate de constructie sau de degradare a pereţilor, de exemplu. Cu toate acestea, în numeroase cazuri apelul la analizele de laborator s-a dovedit a rămâne singura solutie.

Stabilirea relaţjilor stratigrafice fáră de care nici o cronologie nu este posibilă şi interpretarea arheologică a unităţilor stratigrafice care completează această cronologie, constitue două puncte cheie pe care se bazează raţonamentul arheologic.

Pe pagina din dreapta o casetă "note" serveşte la precizarea interpretării unităţii stratigrafice. De exemplu, U.S. 7013 reprezintă un nivel ocupaţional, la rubrica observaţii precizânduse că este o zonă exterioară locuinţei nr.56.

Notele, în măsura posibilului, trebuie să definească informaţile care nu apar nicăieri în altă parte, cum ar fi (de exernplu), relaţiile orizontale, contemporaneitatea diferitelor elemente, etc. Este cazul aici, de informaţille cele mai delicate sau cele mai dificil de obtinut, deoarece nu sunt clar perceptibile la nivelul unui profil stratigrafic şi în general sunt dificil de precizat cu maximă certitudine. Şi aceasta deoarece este nevoie nu numai de înţelegerea totalităţii relaţilor stratigrafice ci şi de necesitatea sustragerii de sub prezența adesea împovărătoare a martorilor stratigrafici sau a diferitelor alte structuri în efortul de a vizualiza ansamblul şi de a determina semnificaţia pe care o putea avea U.S.-ul respectiv în acea parte a sit-ului în momentul dat. Din acest punct de vedere nu există nici tehnici speciale nici soluţii miraculoase. Pentru a rezolva această problemă trebuie să ne bazăm numai pe pertinenţa întrebărilor pe care arheologul le poate pune sit-ului sau pe acelea pe care arheologul insuşi şi le pune, practic pe capacitatea sa de a integra elementele stratigrafice într-un tot unitar şi în consecinţă asupra valorii raţionamentului său.

Pentru facilitarea cercetării integralităţii tuturor informatiilor pe care le putem obşine în cazul fiecărei U.S., fişa include şi alte menţiuni referitoare la alte tipuri de înregistrare al căror subiect a fost. Astfel, ea poate fi reprezentată pe un profil stratigrafic, pe un plan ş̧i pe o fotografie ale căror numere de înregistrare figurează (dacă este cazul) în casetele rezervate pentru aceasta pe fişa de înregistrare. Lafel, sunt întegistrate şi toate prelevările care au fost efectuate.

În paralel cu înregistrarea acestor date "brute" care oferă doar percepţii parţiale ale sit-ului, este indispensabilă redactarea unor note sintetice care să conţină ipotezele sau observaţiile formulate in cursul săpăturii şi care desigur, pot fi modificate, confirmate sau infirmate în funcţie de evoluţia 
săpăturii şi de datele suplimentare apărute. Aceste note, redactate zilnic, pot marca evoluţia reflexiei cercetătoruhui, ajutând în momentul prelucrării datelor stratigrafice, dar ele trebuie utilizate cu grija de a nu înlocui înregistrările brute. În cele din urmă, confruntarea acestor ipoteze cu înregistrarea fină a datelor va permite realizarea unei reconstituiri coerente a "istoriei" sit-ului.

\section{Înregistrarea complexelor}

Dacă unitatea stratigrafică constitue baza înregistrării, în cursul săpăturii apar "evenimente" care nu pot fi ignorate. Ele sunt numite în general incluziuni, perturbări, anomalii ale stratificării, etc. Noi am preferat să folosim termenul de complexe (C). Prin acesta am definit orice depozit a cărui formare nu se efectuează orizontal cum este cazul în general pentru unităţile stratigrafice. În realitate pare să fie mai corectă definirea unui complex nu în funcţie de urmele pe care le lasă într-o stratificare ci mai curând avându-se în vedere maniera în care el s-a format, aceasta dẹoarece el este întotdeauna rezultatul unei acţiüni antropice (pl.III).

Dacă avem în vedere aceasta, putem remarca existenţa unor complexe "pozitive" care reprezintă elementele verticale ce se ridică la suprafata solului (pereţ, ziduri, palisade, etc.), care se contrapun depunerii unităţilor stratigrafice, formând un obstacol şi a unor complexe "negative" care sunt reprezentate de diversele excavări pe care omul le-a practicat de-a lungul timpului (gropi, sanţuri de fundaţie, gropi de bârne, etc.), care distrug în consecţintă, în parte, vestigiile epocilor anterioare. Această distincţie, pe care o facem între complexe şi unităţi stratigrafice poate părea artificială dacă considerăm că un complex (groapă sau şant, de fundaţie), se compun dintr-o serie de straturi de pământ şi că, pe de altă parte, la fel ca şi o unitate stratigrafică, complexul este rezultatul unei activităţi efectuate în aşezare într-un moment dat. Esta adevărat că, această distincţie nu este reală în teorie, dar în practică ea poate permite înţelegerea unei asocieri a unor unităţi stratigrafice (umplutură, de exemplu), şi astfel să se poată permite includerea în cadrul înregistrării a unor informaţil care să evidenţieze modul în care a fost ̣̣tilizat sit-ul de-a lungul ocupării sale.

Remarcăm faptul că acest tip de activităţi s-a dovedit a avea o particulară importanţă în cazul tell-ului de la Hîrşova, afectând în funcţie de diversele momente peste $30 \%$ din suprafaţa cercetată ceea ce antrenează consecinţe majore în cazul studierii mobilieralui deoarece a mare parte a acestuia se găseşte în cadrul acestor perturbări stratigrafice. Este evident faptul că analizarea globală a diferitelor categorii de material, fără a se ţine cont de contextul descoperirii nu poate permite concluzii pertinente şi oricum amendabile.

Fiecare dintre aceste unităti stratigrafice care compun complexul va fi deci înregistrată individual, conform modalităţi descrise mai sus, dar această înregistrare va fi dublată de aceea a complexului, al căruı număr de înregistrare va fi notat şi pe fişa de U.S., sub numărul acesteia (pl. III). Această înregistrare complementară, efectuată pe un caiet special va permite descrierea unei gropi, a unei gropi de bârnă, si studierea unei umpluturi, discutarea interpretării sau a modului de utilizare ca şi efectuarea desenelor corespunzătoare, plan şi profil stratigrafic. Dar în nici un caz, această modalitate de îrıregistrare a complexului şi deci de regrupare a informaţiei, nu trebuie să permită izolarea sa de contextul în care a apărut. În acest moment trebuie să ne punem întrebarea asupra a ceea ce înregistrăm şi ceea cel nu înregistrăm.

Pentru toate complexele negative, (gropi, şanturi de fundaţie, gropi de bârne...) se întrebuinţează un număr fals (fantomă) de U.S. care nu corespunde unei realităţi fizice, dar care permite înregistrarea acţiunii de săpare a complexului. Interesul acestui număr fals constă în aceea că 
permite evidenţierea relaţilor existente între complexul respectiv şi unităţile stratigrafice anterioare şi de a evidenţia utilizările particulare, care nu lasă nici o urma fizică, cum sunt de exemplu gropile sau şanturile de recuperare a unor materiale şi umplute apoi de resturi menajere şi care, deci, nu au nici o legătură cu açjiunea anterioară, care a generat săparea.

Există situaţii în cạre numărul fals este preţios pentru a putea stabili microcrpnologia complexelor de tip groapă de bårnă, care în unele cazuri particulare reprezintă singurele resturi ce ne parvin dintr-o structură sau o situaţie oarecare. Studierea minuţioasă a stratificărilor ce pot fi surprinse în aceste complexe, indispensabilă pentru asigurarea realizării unei bune analize a ocupării sitului nu se poate efectua decât pentru fiecare caz în parte. Ne vom limita la a prezenta în cele ce urmează doar două situả̧̧ii teoretice.

Simplificând evenimentele care pot fi puse în legătură cu o groapă de bârnă, putem afirma că aceasta a fost săpată, utilizată si apoi abandonată. În cele mai multe din cazuri numai, sau doar aceasta din urmă lasă urme semnificative, sau cele mai numeroase.

Principalele modalităţi de distrugere a unei bârne sunt trei: a) smulgerea, care necesită degajarea totală sau parţială a părţii inferioare a bârnei, b), tăierea care se poate efectua la nivelul solului, situaţie în care bârna se va descompune lent lăsând în sol amprenta sa, şi c) indendierea structurii din care aceasta a fácut parte, ceea ce va conduce spre păstrarea în anumite situaţii a lemnului carbonizat în exteriorul dar şi în interiorul gropii. Realizarea acesteia se face aproape întotdeauna în acelaşi mod, prin săparea gropii, mică ca diametru dar profundă şi în care bârna este introdusă, după care ea este umplută astfel încât lemnul este mentinut în poziţia dorită. Dar, între aceste două momente de existenţă a bârnei şi în consecinţă a construcţiei din care face parte, se poate scurge o perioadă de timp mai lungă sau mai scurtă cle-a lunoul căreia această piesă de lemn a format un obstacol în proximitatea căreia s-au format o serie de U.S.-uri. Dacă nu suntem atenţi, înregistrarea unui astfel de complex poate provoca confuzii în ceea ce priveste succesiunea diferitelor momente în special in ceea ce priveste perioada de utilizare şi cea de distrugere a bârnei respective. Pentru a se facilita interpretarea, dar mai ales pentru a fi obligaţi să întelegem toate evenimentele, se foloseste utilizarea acestor numere false care reprezintă utilizarea bârnei şi distrugerea.

Se obţine deci în fiecare caz o schemă care reprezintă ceea ce s-a petrecut în realitate şi deci permite stabilirea cronologiei corecte a evenimentelor. Este evident că în atari circumstanţe devine imposibil să se poată confunda, distrugerea cu u.s.-ul corespunzând construirii structurii. Dacă atribuirea de numere false, în timpul săpăturii, poate părea ca fiind adeseori inutilă, experienta ne-a demonstrat că această modalitate ne-a obligat atât în timpul săpăturii cât şi în timpul interpretării datelor legate de activităţile aferente complexelor respective, să realizăm o analiză completă care să poată pure în valoare atât durata cât şi funcţiunea respectivului complex. Dar în acelaşi timp trebuie să recunoaştem că dacă acest mod de a proceda ne-a permis o mai bună înţelegere a multiplelor săpături întâlnite pe tell-ul de la Hîrsova, determinarea precisă a relaţilor stratigrafice a nenumăratelor gropi de bârne şi mai ales de ţăruşi observaţi pe sit a rămas adesea foarte dificilă. Şi aceasta în condiţiile în care este cazul unor elemente extrem de importante din punctul de vedere al arhitecturii.

În cazul complexelor pozitive am procedat în aceeaşi manieră, cu menţiunea că în cazul unui sit urban, majoritatea acestor structuri verticale este reprezentată de ziduri. Pentru a facilita referirea la aceste fapte importante puntru istoria sitului, se foloseste utilizaree unor numere, nu de complex ci de pereţ, modalitate care permite prin intermediul atribuirii unei secvente numerice, memorizarea lor mai bună şi în consecinţă mai buna lor descriere şi discutare individuală. Astfel de discuţii sunt 
indispensabile pentru înregistrarea elementelor care privesc tehnicile de construcţie şi pentru a indica relaţiile pe care eventual ele le pot avea cu alte serii de fapte. Căci esocierile de fapte, pereţ şi niveluri ocupaţionale constitue esenţialul studiului unui sit şi ele trebuie observate în cursul săpăturii, atunci când ele apar, altfel ele vor fi aproape imposibil de stabilit. Tell-ul de la Hîrşova prezintă o dificultate suplimentară deoarece aici lipsesc zidurile de piatră. Pereţii construcţiilor sunt aici mult rnai dificil de văzut, creindu-se o situaţie mult mai delicată decarece există în cele mai multe din cazuri pereţi aflaţi în diverse stadii de degradere şi deci cu atât mai dificil de observat şi interpretat. În consecinţă, pereţii diferitelor construcţii au fost notaţi şi discutaţi la fel ca şi complexele.

Toate relaţiile care pot exista între un perete sau o perturbare stratigrafică (săpătură) şi diferitele unităţi stratigrafice trebuie deci să fie definite şi să facă obiectul unor note sintetice care să-și găsească locul în înregistrarea complexului însuşi. Înregistrarea completă a fiecărui complex necesită şi realizarea unui plan la scara $1 / 20$, în conexiune cu caroiajul sitului şi evident şi un profil stratigrafic al umpluturii. Acestea pot fi multiplicate după caz, atunci când se consideră necesar pentru a se putea surprinde şi înregistra eventuala complexitate a situaţiei. În ceea ce priveste scara de $1 / 20$, aceasta a fost aleasă în virtutea faptului că ea permite reducerea într-o manieră convenabilă, adică posibilitatea de a se obţine documente de şantier care să permită înţelegerea situaţillor din teren dar şi lucrul cu foi de hârtie milimetrică cu dimensiuni ce permit folosirea lor mai uşoară şi care în acelaşi timp nu necesită reconversii prea dificile sau numeroase. Realizarea de documente la scara $1 / 10$ s-a dovedit a fi necesară doar în situaţii în care care o impun. Această scară este utilizată în cazul unor stratificări complexe, în cadrul cărora nu de putine ori întâlnim U.S.-uri cu grosimi centimetrice sau chiar mai putin.

\section{Înregistrarea structurilor de locuire}

Complexitatea structurilor pe care le-am întâlnit, pe sit-ul de la Hîrsova precum şi stratificarea lor internă a condus spre o anume dublare a înregistrărilor unităţilor stratigrafice şi a complexelor prin intermediul ulır fişe suplimentare : fişele de structuri de locuire. Acestea permit regruparea unor numeroase complexe, de genul şanţuri de fundaţie, gropi de bârne, sau de ţărusi, cuptoare, vetre etc.) şi multiplele unităţi stratigrafice (construcţie, ocupaţional, distrugere...) ce fac parte dintr-o aceeaşi construcţie şi de a grupa toate datele precum şi ipotezele referitoare la evoluţia şi organizarea sa. Tot aici pot fi înregistrate datele de far.tură etnografică care demonstrează existenţa unor sisteme de constructie sau amplasarea diferitelor ansambluri de mobilier, de exemplu ( $\mathrm{pl.I} / \mathrm{b}, \mathrm{V} / \mathrm{a}, \mathrm{b}$ ).

Aceasta reprezintă o completare a sistemului utilizat în cazul sit-urilor urbane istorice în care datele de natură etnografică referitoare la utilizarea diferitelor segmente ale spaţiului interior sunt rareori conservate (pl.IV).

\section{Profilele stratigrafice}

Utilizarea tehnicii "open area", presupune necesitatea expunerii pe toată suprafaţa săpată a diferitelor niveluri contemporane aparţinând unor momente evolutive ale sit-uluil. Aceasta nu este posibilă decât prin demontarea periodică a martorilor stratigrafici. Obiecţia principală ce poate fi formulată împotriva unei astfel de practici constă în aceea că ea de fapt privează arheologul de existenţa unor martori privilegiaţi care regrupează informaţiile privind istoria sit-ului, în tirmp ce existenţa acestora permite în orice moment recitirea, reinterpretarea, dacă este necesar, a istoriei deja 
săpate a respectivului sit. Această obiecţie poate fi considerată ca fiind nejustificată dacă se iau o serie de precauţiıni elamentare, care astfel să evite pierderea unor informaţil stratigrafice. 0 dată aceste precauţiuni luate, săparea martorilor stratigrafici nu pune în sine mai multe probleme decât săparea oricărei unităţi stratigtafice. În primul rând trebuse ca profiluł respectiv şă fie cu atenţie studiat şi în consecinţă bine înţeles. Din acest punct de vedere credem că nu mai este necesar să mai amintim sfaturile generoase ale lui Sir Mortimer Wheeler (Wheeler, 1956, 56-79) şi care rămân în continuare foarte preţioase, atunci când se referă la necesitatea realizării unor martori stratigrafici perfect verticali ce trebuie curăţ̧̧i periodic astfel încât profilele să fie iizibile în permianentă.

În acest sens, este evident că necesitatea studierii la mici intervale de timp se dovedeşte a fi benefică pentṛu întelegerea săpăturii, căci experiența a demonstrat că din nefericire, mai ales în cazul unor săpături ce trebuie să fie efectuate în intervale de timp foarte scurte, conducătorul săpăturii se concentreaza mai curând asupra înregistrării U.S.-urilor, considerând de cele mai multe ori că va avea timp mai târziu pentru studiul profilelor stratigrafice.

Dar în cazul sit-uriior cu o stratignfie cemplexă sau în cazurile în care martorii pot atinge înălţimi de mai multi metri, studiul acestora s-a dovedit a fi foarte dificil în special datorită faptului că întelegerea globală a lor este dificilă, mai ales în situaţia în care partea superioară a depozitului arheologir, a fost săpată cu mai mult timp înainte. În aţari situaţii ,de regulă se produce 0 anumită simplificare a lecturii profilului, lesne de înţeles mai ales atunci când el poate include câteva mii de U.S.-uri, deoarece altfel înţelegerea globală a profilului este foarte grea dacă nu devine chiar imposibilă. În schimb, existenţa pe o perioadă de timp limitată a martorilor stratigrafici impune studierea atentă a acestora de către conducătorul săpăturii, crescând astfel calitatea înţelegerii acesteia.

Un aspect important al acestei pronleme constă din înregistrarea integrală a informaţiei stratigrafice şi prin intermediul unui desen, efectuat bineânteles la scară, care este destinat să înlocuiască profilul stratigrafic complet. De cele mai multe ori noi am utilizat scara de $1 / 10$ care trebuie realizată cu o precizie extrema. Pentru aceasta este irnperios necesar să se utilizeze o origine orizontală şi una verticală, constante, ceea ce impune utilizarea unei minime dotări tehnice, fără de care această precizie nu poate fi posibilă. Dacă se vor utiliza şi aceleaşi puncte de reper, iar U.S.-urile vor fi desenate cu maximă exactiturline, completarea succesivă a desenului nu va pune nici o problemă, în cele din urmă el prezentând întreaga succesiune stratifgrafică prin adăugarea noilor elemente celor deja desenate. Dar, ceea ce trebuie să subliniem, este că reperajul topografic şi altimetric jaacă un rol primordial. Este indispensabilă plaşarea în fiecare campanie de şăpături a limitelor caroiajului şi în egală măsură deci a martorilor stratigrafici, în condiţile în care trebuie de asemeni utilizate aceloraşi axe, verticale şi orizontale.

Aspectul grafic al desenelor, î respectå pe acela preconizat de Sir Mortimer Wheeler(1956, 76), conturul şi numerele fiecărei unităţi stratigrafice fiind net reprezentate. În această situatie noi am preferat utilizarea unui cod concretizat prin culori, fapt care chiar dačّ ar putea părea lipsit de importanţ̌, îşi are valoarea sa deoarece permite lectura relativ rapidă a desenelor. În principiu, utilizarea profilelor stratigrafice, concretizate prin martorii stratigrafici poate să nu se rezume numai la existenţa profilelor care coincid cu limitele sectoarelor, acestea putând fi create ori de câte ori esfe nevoie, în orice loc al săpăturii, dacă se consideră că este necesară asigurarea unei cât mai bune întelegeri a unei situaţii anumite sau a unui complex. Desigur, de fiecare dată aceste secţiuni şi profilele ce rezultă vor fi desenate la aceeaşi scară, astfel încât să existe pe de o parte o anumită 
coeziune a documentaţiei, dar şi să fie asigurată o întelegere mai rapidă a săpăturii. (Astfel, poate fi secţionată zona unei treceri dintre două camere cu scopul de a se putea surprinde clar şi cu maximă certitudine relaţile stratigrafice dintre cele două camere.).

\section{După studiere (înţelegere) si înregistrare-desenare, se poate trece la demontare.}

În acest moment al săpăturii se plasează o operaţie care aparţine mai curând înregistrării unităţilor stratigrafice, dar pe care o descriem aici, deoarece acesta este momentul în care ea apare în timpul săpăturii. De la bun început am subliniat că unităţile stratigrafice sunt numerotate în cadrul sectoarelor realizate din caroierea zonei ce urmează a fi săpată. Deci, până în momentul în care martorii stratigrafici vor fi demontaţi, zona este compusă dintr-o serie de sectoare alăturate care pot fi la nevoie privite drept mici sit-uri independente. Dar o asemenıa parcelare a săpătarii evident că afectează înţelegerea globală a acesteia şi deci "legarea" lor câte două (de exemplu) prin stabilirea corelaţiilor ce pot exista între U.S.-urile din interiorul lor. Aceasta se poate face în momentul săpării extrem de minuţioase a martorilor stratigrafici, deoarece numai în acest moment se pot stabili, dacă există!, relaţiile fizice de continuitate sau de suprapunere între diverse unităţi. Aceste informaţii vor fi notate pe fişele de U.S. sub numărul de ordine alături de semnul =. Aceste corelaţii au 0 importanţă capitală sentru reconstituirea stratificării complete a sit-ului. Această operațle este la rândul ei posibilă numai în condiţiile în care, pe parcursul săpării U.S.-urilor, numerele de înregistrare ale acestora scrise pe mici etichete (de regulă de material plastic pe care numerele de înregistrare urmează să fie înscrise Cu ajutarul unui tuş care nu se șterge, îndeosebi sub efectul saarelui sau al ploilor) vor fi plasafe cu ajutorul unor cuie în martorii stratigrafici pe locul în care respectivele U.S.-uri se conservă în martorii respectivi.

Trebuie încă o dală să subliniem că aparenta contradicţie co există ca urmare a săpării în sectoañ delimitate de martori stratigrafici poate fi eliminată ca urmare a limitării independentei sectoarelor în principal numai la modalitatea de înregistrare, astfel putându-se realiza expunerea așezăril în ansamblu. Chiar cu riscul de a ne repeta, trebuie să insistăm în mod absolut asupra necesităţii reflexiei arheolagice pe teren, aceasta fiind singura modalitate de a recunoaste apariţia unor noi elemente care să reprezinte un alt moment al evoluţiei sit-ului, situație care trebuie înregistrată şi fotografiată la rândul ei. Este desigur imposibil să prezentăm łoar în câteva cuvinte modalitatea ce permite atingerea acestui rezultat care în fapt nu se bazează decât pe o bună înţelegere a sit-ului şi pe o perfectă experienţă de teren. Totodată se poate întâmpla ca natura momentului pe care îl atingem în cursul săpăturii să difere de momentul ulterior, ce va fi atins.

Fiecare dintre aceste momente odată surprins în integritatea sa, trebuie înregistrat şi fotografiat.

\section{Desenarea planurilor}

Devenite necesare în primul rând datorită caracterului distructiv al săpăturii, planurile permit conservarea imaginii sit-ului într-un moment dat. Este evident faptul că de fiecare dată câno ne pregătim să realizăm un plan al unei structuri, a unei unităţi stratigrafice sau a unei zone în integralitatea sa intr-un moınent al ş̆oăturii, trebuie să ne întrebăm oe anume aşteptăm de la acest desen plecând de la ceea ce va figura pe plan. Reţinem că prea adesea, există o utilizare anarhică a planurilor desenate, realizate şi ele adesea cu ocazia realizării unor curățenii ale săpăturii şi deci, în consecintă, regrupează fără distincţie elemente ce pot aparţine unor momente sau chiar epoci diferite, sau sunt folosite în mod sistematic pentru a conserva urmele unor elemente mai putin sau de loc 
inţelese (pietre într-un nivel, obiecte în loc, etc.) care sunt astfel reprezentate pe o foaie de hârtie milimetrică, de cele mai multe ori izolate de contextul lor.

Realizarea unui plan este o operaţie de multe ori lungă şi care în consecinţă întârzie uneori în mod considerabil săpătura. Iată de ce trebuie să ne asigurăm că această operaţie va fi pertinentă. Noi am decis să folosim la Hîrşova două feluri de planuri. Planuri parţiale care ne permit să întelegem un aspect particular al asezării (diferite complexe, pereţi, grupări de mobilier,etc.) şi planuri generale destinate să conserve diferite momente ale săpăturii. Primele, vor avea drept subiect întotdeauna suprafeţe limitate şi deci vor fi realizate plecându-se de la axele de caroiaj ale săpăturii, pentru a putea fi la nevoie transferate pe un plan general al săpăturii. Utilizarea unei scări comune poate facilita în rnodi considerabil această operaţie. Dar, oricum, în asemenea situaţii trebule să ne asigurăm că toate elementele pertinente vor fi reprezentate şi că planul respectiv va prezenta toate elementele necesare pentru ca integrarea sa eventuală în planul general să poată fi făcută (date referitoare la caroiaj, ruumerele diverselor unităţi stratigrafice, numerele complexeler, orientarea, cotele altimetrice, etc.)

Planurile generale ce reprezintă stadiul general al săpăturii, relizate întotdeauna pe mari suprafeţe, având în vedere importanţa şi complexitatea lor trebuie să fie încredinţate spre realizare unor membri cu experienta ai echipei. Desigur, pentru realizarea lor este indispensabilă existenţa unui caroiaj fix al sit-ului, care realizat la începutul săpăturii nu va mai fi apoi modificat, el fiind acelaşi de-a lungul tuturor campaniilor de săpături. Mai multe soluţii pot fi avute în vedere pentru realizarea acestei grile, în funcţie de mijloacele materiale de care se dispune sau în funcţie de tipul interventiei avute în vedere. Se poate - după cum recomandă Sir Mortimer Wheeler- realiza o grilă constituită din linii ortogonale distantate la 4 metri, dar relizarea sa poate determina apariţia anumitor constrângeri ce pot la rândul lor să încetinească în mod considerabil săpătura. Într-adevăr în cazul sit-urilor cu o densitate mare a locuirii utilizarea unui astfel de cadru rigid poate conduce spre "fragmentarea" săpăturii care poate reprezenta o dificultate majoră în înţelegerea diverselor structuri arheologice. Acesta este şi cazul aşezărilor urbane unde întrepătrunderea diverselor construcţii succesive se acomodează greu unei asemenea tehnici.

O metodă folosită cu succes de către Martin Biddle în cazul asezărilor de la Winchester si descrisă de către el (Biddle \& Kjolbye-Biddle, 1969,208-210) constă în aplicarea în asezare a unui caroiaj Lambert care permite desemnarea oricărui punct al asezării prin intermediul a două coordonate. Această metodă oferă incontestabile avantaje, mai ales în cazul în care ne găsim în situaţia unui sit în care săpătura poate fi extinsă în toate direcţiile, dar ea presupune existenţa unei infrastructuri grele şi realizarea unor relevee topografice precise pe mari suprafețe.

În cazul tell-ului de la Hîrsova s-a optat pentru conservarea grilei de $\mathbf{2} \mathbf{m}$. folosită de la începutul săpăturii. Ea serveste pentru toate planurile şi profilele care sunt executate din 6 în 6 metri.

Desenarea elementelor din interiorul caroiajului poate fi executată

cu ajutorul metrului rectangular (pl.V) racordat perfect la axele caroiajului. Această tehnică este mult mai rapidă decât aceea a triangulării care poate fi utilizată într-un număr mai mic de cazuri. Desigur, cadrul respectiv este perfect orizontal şi măsurătorile sunt efectuate ctı ajutorul firılui cu plumb pentru a se evita erorile de paralaxă.

Desenarea fiecărui moment important al săpăturii prezintă bineînteles avantajul de a putea fi comparate între ele atunci când nu mai există în teren. Şi nu poate fi o modalitate mai bună de a compara două planuri decât suprapunerea lor. Aceasta explică de ce este bine dacă ele sunt realizate 
pe un suport transparent. Dar, în acelaşi timp, calcul milimetric, organic sau nu, este foarte sensibil la variatiile de temperatură sau umiditate ceea ce-l face dificil de utilizat. Aceste este motivul pentru cace am optat pentru utilizarea la Hîrşova a unor suporturi plastice transparente care nu se deformează şi oferă avantajul de a putea fi utilizate tot timpul.

După ce au fost stabilite principiile, tehricile şi suportul ce va fi utilizat, trebuie stabilit ce anume va fi desenat şi cum va fi figurat pe plan.

Trebuie realizat de la bun început, caroiajul general al zonei ce urmează a fi desenată cu scopul de a se pune în evidenţă toate elementele ce urmează a fl desenate, în cele mai mici detalii (limitele unităţilor stratigrafice, ale complexelor, pereţilor, mobilierului, etc.), moment după care responsabilul săpăturii trebuie să-i indice celui ce urmează să execute desenul toate elementele ce urmează să fie trecute pe plan. Acesta este momentul în care trebuie precizate elementele care în mod normal nu pot apărea sau riscă să nu fie foarte vizibile în fotografii, cum ar fi de exemplu limitele unităţilor stratigrafice, şi de a se exclude elementele posterioare cum ar fi gropile sau diversele alte intervenţii care au distrus o parte din structurile ce se doreşte a fi desenate. În cazul profilelor utilizarea unor convenţi sau a culorilor facilitează în mare măsură citirea si interpretarea lor dacă avem grijă să fie utilizate în permanenţă aceleaşi convenţii (coduri).

Odată realizat desenul el trebuie completat cu cotele altimetrice pentru a se putea indica adâncimea diverselor elemente întotdeauna calculate de la aceeasi altitudine (punctuł 0 al săpăturii). Pe plan trebuie trecute întotdeauna numerele de înregistrare a diferitelor elemente (unităti stratigrafice, complexe, etc.) iar pe margine toate elementele ce permit intelegerea lor (orientare, scară, descriere). Responsabilul săpăturii trebuie să se asigure că desenul odată terminat cuprinde toate elernentele indispensabile pe care va trebui să le şi verifice.

Dar chiar dacă planul odată realizat va conserva momental respectiv în care se află săpătura, în cele mai mici detalii, el va rămâne prea tehnic pentru a permite vizualizarea ansamblului redat necesitând un efort suplimentar din partea lectorului. În această situaţie, fotografia rămâne cea mai elocventă.

\section{Înregistrarea fotografică}

Problemele ridicate de utilizarea fotografiei privesc atât tehnica propriu-zisă cât şi înregistrarea clişeelor. În ceea ce priveste tehnica fotografierii ne mujtumim să afirmăm că este adesea benefic şi chiar mai uşor să-i fie încredinţată arheologului sarcina de a realiza această operatie decât anui fotograf ce se interesează de arheologie.

Înregistrarea fotografică eficace a unui sit necesită într-adevăr din partea celui care o realizează o bună cunoastere a problematicii arheologice în general cât şi a sitului în special, astfel fiind capabil să asigure un bun cadraj, cel mai apt să pună în evidentă cele mai relevante detalii; imaginile pot servi fie pentru înregistrarea unor aspecte particulare ale diverselor situaţii şi în acest caz pot fi considerate drept instrumente de lucru, fie pentru a furniza ilustraţia necesară publicării rezultatelor săpăturii. Este evident faptul că din acest punct de vedere, la Hîrşova, nu am fotografiat numai vederi generale ale săpăturii ci am selecţionat un număr de detalii necesare înregistrănii diferitelor structuri. 
Desigur, ca şi în cazul desenului, suprafaţa ce urmează a fi fotografiată a fost bine curătată astfel încât ceea ce se doreşte să se înregistreze să fie bine pus în evidenţă iar înţelegerea să nu fie perturbată.

Noi am decis iniţial să efectuăm de fiecare dată o dublă fotografiere, o dată utilizând peliculă alb-negru si odată peliculă diapozitiv color de $35 \mathrm{~mm}$, destinată a putea fi proiectată pentru ilustrarea diverselor intervenţii publice de prezentare a săpăturii. Ulterior am decis ca fotografierea să se facă în trei exemplare (atunci cînd a fost posibil), două exemptare fiind destinate nu numai prezentării în cadrul reuniunilor ştiinţifice dar şi în cadrul pregătirii profesionale a studenţilor, cel de al treilea rămânând în rezervă urmînd a fi utilizat numai în situaţii deosebite. Utilizarea de filme negativ color pentru telizarea de fotografii ni se pare că nu prezintă un mane interes deoarece pe de o parte sunt în general scumpe iar pe de alta nu pot fi utilizate pentru publicare decât în situaţi rarisime. Oricum, dacă este într-adevăr nevoie, tehnicile de realizare de fotografii color prin copierea diapozitivelor dau în prezent rezultate satifăcătoare.

Pentru a facilita de asemeni lectura clişeelor am optat pentru utilizarea în planul ales a unei scări metrice şi/sau a unei plachete pe care am amplasat întotdeauna indicatiile pe care le-am considerat minimale pentru a putea identifica imaginea (număr de complex sau de unitate stratigrafică), desigur fără a masca imaginea aleasă pentru fotografiat. Varianta plasării literelor de plastic pentru aceste coduri direct pe pământ deşi prezintă avantajul de a nu afecta decât foarte puţin din suprafaţa ce urmează a fi fotografiată, sunt din aceeaşi cauză foarte puţin vizibile, impietând asupra lecturii clişeelor. Acestea la rândul lor au fost înregistrate într-un inventar de şantier, completat de fiecare dată când se fac fotografii, în care se notează datele importante ale subiectului, unghiul de vedere din care a fost efectuată fotografia, explicaţia mai extinsă a subiectulul şi chiar datele foerte tehnice (diafragmă, timp de expunere), numele celui care a făcut fotografia şi data la care a fost efectuată.

Înregistrarea pe şantier a clişeelor făcute trebuie să fie acompaniată de numerotarea lor în functie de sit si zonă (7.1032 = cliseal nr.32 a zonei 1 a sit-ului 7) care va fi trecută pe marginea negativului. Pentru a se evite manipularea negativului şi pentru a se evita riscul apariţiei deteriorării negativului este foarte utilă realizarea unor fotografii după fiecare negativ, grupate la rândul lor în albume care trebuie să conţină şi legendele fiecăruia. Astfel se poate facilital accesul la negative, de fiecare dată când este nevoie, prin consultarea acestui album.

Diapozitivele la rândul lor au fost ordonate în aceeaşi manieră, toate indicaţiile necesare fiind incluse în fişe speciale, la rândul lor încorporate într-un index.

Cu examinarea tehnicii de săpătură şi înregistrare rezultate din arheologia urbană şi utilizate la Hârsova, am trecut în revistă metodele ce permit recoltarea într-o manieră sistematică a datelor furnizate de stratificarea dintr-un sit şi care privesc de asemeni evenimentele punctuale reprezentate de unităţile stratigrafice ca şi aspectele mai generale ale sitului reprezentate de diferitele complexe sau structurile de locuire, semhalând pentru fiecare operaţie precauţiunile pe care trebuie să le luăm pentru a se putea garanta exhaustivitatea şi pertinenţa studierii şi înregistrării dạtelor. 


\section{Exploatarea datelor stratigrafice: operaţiunile de prelucrare.}

Înregistrarea unitł̆ţilor stratigrafice și a complexelor, efectuată în cursul săpăturii conţine informaţii stratigrafice în ordinea în care au fost ele colectate iar numerotorea lor nu coincide cu ordinea în care au fost înregistrate. În cea mal mane parte de timp, această ordine este foarte diferită de cea în care ele au fost furnizate, căci, în cazul în care mai multe uniť̆ţi stratigrafice apar după efectuarea unui decapaj şi trebuie înregistrate este adeseori imposibil să li se precizeze succesiunea. Pe de altă parte, ordinea înregistrării depinde de deciziile luate în cursul săpăturii, în sensul că la un moment dat săpătıra poate fi direcţionată cu prioritate asupra unui sector şi fiind abandonat un altul. În aceste condiţii există posibilitatea de a nu se avea o vedere de ansamblu asupra sitului iar specialiş̧ii ce prelucrează o categorie particulară de informaţii (ceramică, utilaj de corn, etc.) nu vor putea avea la dispoziţie informaţii precise asupra contextului stratigrafic al materialului de care se ocupă.

Această înregistrare constitue ceea ce se numeste în fotografie imaginea latentă imprimată pe negativ dar care nu poate fi utilizată fără un tratament specific. În consecinţă este recesar ca acest negativ să fie "developat" astfel încât el să devină vizibil. În cazul nostru aceasta înseamnă că va trebui să fie reconstituită succesiunea formănii şi depunerii fiecărei unităţi stratigrafice. Acest scop va putea fi atins la capătul a mai multor operaţiuni care, chiar dacă par fastidioase, se constitue in modalitatea prin care vor putea fi verificate ipotezele si concluzile formulate pe teren ce pot $\mathrm{ft}$ confruntate cu datele brute. Am subliniat deja dificultatea integrării fieç̌rei date în raţionamentul de teren şi de a lua în considerare, acordându-le valoarea exactă, toate informaţille oferite de către fiecare unitate stratigrafică. Aceste diverse operaţii constitue modalitžţile de a elimina riscurile de eroare ce se pot datora elaborării unei sinteze formulate în cursul săpăturii, care simplifică informația. La capătul acestora se poate obţine o mai bună vedere de ansamblu a istoriei sit-ului acordând informaţiilor reala lor valoare istorică.

\section{Punerea în secvenţă}

Prima operaţie constă în restabilirea ordinii în care s-au depus unităţile stratigrafice, care astfel va fi capabilă să ne furnizeze crronologia relativă a diverselor elemente fără de care nici un discurs arheologic nu este posibil.

În cadrul acestei prime activiţ̌ţi rıu vor fi exploatate decât operaţiile de ordin cronologic care pot fi decelate din relaţiile fizice a unităţilor stratigrafice între ele şi care ne sunt furnizate de către înregistrarea fácută pe teren (fişele de U.S., profilele, planurile sau fişele de complexe, de exemplu).

Se pot, de asemeni, regrupa pe sectoare toate înregistrările pe diagrame care pot să pună in evidenţă toate aceste realităţi. Teoria elaborării unui astfel de grafic a fost studiată în detaliu de către Edward Harris (Harris, 1975, 109-121). Astfel, sunt rezumate cele trei sensuri în care aceste relaţii pot exista: un u.s. paate fi sub, pe sau egal cu o altă unitate stratigrafică. Relaţia pe/sub se reprezintă grafic prin intermediul unei linii verticale, numerele ce corespund celor două u.s.-uri fiind plasate unul sub altul, iar relaţia de echivalenţă este reprezentată prin semnul = ce leagă numerele celor două u.s.uri care vor fi plasate la acelaşi nivel. Aceste relaţii sunt adesea multiple (o unitate stratigrafică acoperind mai multe unități stratigrafice sau fiind acoperită de mai multe). Pentru reprezentarea grafică a unei astfel de situaţii se procedează după cum am menţionat mai sus, cu observatia că în loc de un singur număr de u.s., pot apărea mai multe (v. în acest sens şi diagrama stratigrafică a C. 521 din raportul asupra săpăturilor de la Hîrşova-tell, din prezentul volum). Trebuie să precizăm că în 
elaborarea unui astfel de grafic trebuie studiată cu cea mai mare grijă înregistrarea deja făcută a acestor relații iar reprezentarea lor trebuie de asemeni fácută cu cât mal mare claritate, astfel încât să nu se poată produce nici o confuzie.

Pentru fiecare sector al aceleiaşi zone, un grafic de acest fel va fi realizat, exploatánd independent şi confruntând informaţile rezultate din înregistrarea unităţilor stratigrafice şi relevee. Această confruntare permite eliminarea erorilor care se produc adesea (relaţii stratigrafice inversate sau omise...) în cazul unui sit co stratigrafie complicată şi săpat ln intervale de timp limitate. Se obţine astfel pentru fiecare sector o imagine a ordinii depunérii unităţilor stratigrafice, fiecăreia dintre ele fiindu-i conferită aceeași valoare, în care fiecare element este considerat drept un eveniment ce face parte din istoria sit-ului. În acest moment, graficele astfel realizate nu permit încă o viziune de ansamblu asupra stratificării complete a zonei. În consecinţă ele trebuie legate între ele utilizându-se corelaţiile existente între diferitele unităţi stratigrafice operate într-un sector sau altul în cursul demontări martorilor. De exhaustivitatea corelărilor efectuate în cursul săpăturii va deplnde precizia graficului final ce se bazează pe reconstituirea exactă a stratificării.

Articolul lui Harris citat tinde să arate că trebuie să obţinem un grafic care se dezvoltă întrun ax aproapa exclusiv vertical: aceasta se verifică în parte în cazul sit-urilor care prezintă o stratigrafie simuplă şi unde relaţile cle anterloritate sau posterioritate nu au fost obliterate. În cazul săpăturilor extinse ca suprafał̧ă, efectuate în sit-uri locuite mult timp, se pot întâlni adesea serii de unităţi stratigrafice paralele în cazul cărora nu putem stabili aceste relaţii. Astfel nu vom putea stabili dacă două cuptoare ao fost utilizate în acelasi timp dacă ele au fost acoperite de un acelasi nivel. La fel, de exemplu, apar situaţii frecvente în care nu putem lega între ele două serii de uniţ̧̧ı ce se dervoltă de o parte şi de alta a unui perete sau sunt separate de un şant de fundatie posterioară. Practic, în asemenea situaţii trebuie să ne adaptăm caracterului lacunar al informaţiilor stratigrafice.

Am arătat în acest articol, redactat în momentul în care metoda era folosită, existenta unui abuz de teoretizare care împinge autorul să suprime toate relaţile care riu sunt directe. Această simpificare s-a dovedit a fi periculaasă în practică, deoarece ea suprimă o parte a relaţilor stratigrafice. În această situaţie trebuie să ne întrebăm care sunt cauzele ce conduc spre situaţia conform căreia (de. ex.) o parte a a stratului numerotat 4 să constitue încă suprafaţa sit-ului în momentul în care alt strat numerotat $1 \mathrm{~s}$-a format: fie sit-ul a fost nivelat între momentele reprezentate de cele două unităti stratigrafice, fie a evoluat foarte puţin între momentul reprezentat de depunerea unităţii 4 si unităţii 1 , dar trebuie ca acest contact între 1 şi 4 să fie notat în punerea în secvenţă. De asemeni, a fost evident faptul că această simplificare priva specialiştii ce lucrează asupra mobilierului de un element de interpretare important. Dacă admitem că 1 este o depunere medievală si 4 un nivel ocupational din perioada Imperiului roman, este posibil ca urmare a unor imprecizii de săpătură (1 nefiind săpat complet înainte de a se proceda la săparea lui 4), unele mici fragmente medievale să se găsească amestecate cu materialul roman din 4. Având la dispozitie diagrama stratigrafică, ceramologul se va găsi în situaţia de a putea explica prezenta aoestor elemente târzii, în condiţiile în care o simplă privire a acestuia i-ar putea permite să vadă că aceste două unităţi se găsesc în contact direct. Aceasta i-ar putea permite să explice imediat contaminarea. În consecinţă trebuie să adoptăm principiul conform căruia se vor nota toate relaţiile fizice care au fost observato în timpul săpăturii pentru a se putea evita lungile căutări din partea celor care trebuie să utilizeze informaţia stratigrafica. 
Graficul final ajută la sintetizarea relaţiilor stratigrafice pentru ansamblul zonei şi regruparea secvenţelor ( $v$. diagrama secventelor C. 521 din raportul Hîrşora-tell dih prezentul volunı). Trebuie să precizăm că acest grafic nu vizează să prezinte o viziune spaţială a complexului ci numai să stabilească ordinea cronologică a depunerii uniţ̧ţilor stratigrafice şi relaţile existente între ele, el fiind utilizat pentru a se evita, în destule cazuri, necesitatea utilizării unor note ce pot fi complicate sau chiar mai abstracte decât reprezentările grafice.

Odată existentă această cronologie reconstituită este posibilă realizarea unei reflexii arheologice care va atribui fiecăruia din aceste evenimente o valcıare informativă proprie. Acesta nu este încă, pentru moment, un document critic ce poate fi utilizat usor. Abia din acest moment începe ceea ce numim "punerea în secventă". Acest termen, de secvenţă, desemnează un grup de unităţi stratigrafice, uneori una singură, care au fost produse de o aceeaşi operaţie (acţiune/activitate): diferite tipuri de deşeuri, cărbune de lemn, cenuşă, solzi de pește... multe resturi diferite ale unei aceleaşi ocupaţii de exemplu.

Scopul cercetării este acela de a reconstitui istoria evenimenţială a sit-ului întrebându-ne asupra originii fiecărui depozit. Pentru aceasta dispunem de descrierea unităţilor stratigrafice şi în primul rând de interpretarea lor arheologică. Ar fi logic, pentru că scopul operaţiei este de a reconstitui istoria sitului de a proceda de jos în sus, adică de la cel maai vechi la cel mai recent, dar experienţa ne arată că avem mai curând interesul de a efectua acest demers în sens invers. Acesta este cazul recompunerii săpăturii întocmai cum s-a desfăşurat, evitând să ne lăsăm influenţati de ipotezele formulate în cursul săpăturii şi de a construi o istorie bazată pe propriile teorii decât să ne bazăm pe datele rezultate din săpătură. Ipotezele amintite, trebuie verificate şi adesea se constată că unele unităţi stratigrafice atribuite pe teren priniei faze de existenţă a unei construç̦ii apartin în fapt unei alta, ulterioare.

Determinarea secvenţelor necesită cea mai mare prudenţă, deoarece o temeritate excesivă manifestată în acest stadiu va sfânş̧i prin a regrupa elemente a căror contemponeraneitate nu este garantată de nimic, ele putŝñ fi rezultatul unor operaţiuni diferite sau al unıor operaţiuni asemănătoare dar care nu sunt contemporane. În consecinţă, studiul mobilierului nu va putea fi efectuat într-o manieră convenabilă. Invers, o timiditate abuzivă poate determina izolarea fiecărei unităţi stratigrafice într-o secvenţă proprie, situație care va face fastidioase studiile ulterioare. Principalul pericol la care ne putem expune în timpul acestei operaţii constă din cedarea spre facil şi de a se practica un decupaj mecanic. Numai raţionamentul arheologic permite constituirea secvenţelor şi nici un element nu trebuie ignorat. Analiza complexalor va fi efectuată conform aceleiaşi reguli şi elementele lor componente pot constitui părţi ale unor secvenţe diferite.

Pe baza secvenţelor astfel determinate se poate trece la studiul mobilierului şi în consecinţă este neciesăr să se poată pune la dispoziţia celorlalti membri ai echipei nu numai diagrama unităţilor stratigrafice şi a secvențelor dar şi identificarea cu explicarea şi prezentarea raţionamentului care a permis definirea lor. În consecinţ̆ trebuie redactate note de punere în secvenţă, care cuprind pe lângă grafic, un index al tuturor unităţilor incluse, ele trebuind să permită tuturor celor implicaţi să ştie în care secvenţă a fost inclusă fiecare dintre unităţ. Acest index permite regăsirea cu uşurinţă a contexextului în care a fost descoperit un obiect (cu numărul său de inventar) şi permite deasemeni verificarea includerii fiecărei unităţi în acest grafic. Se adaugă la acestea, note ce prezintă succesiunea secvenţelor care regrupează mai multe categoni de informaţii cum sunt numărul şi descrierea sumară a unităţilor stratigrafice ale secvenţ̧ei, relaţiile lor stratigrafice, interpı etarea arheologică a secvenţelor, 
natura acţiunilor antropice care le-au generat, urmând apoi numerele de secvenţă, fază şi perioadă. De asemeni, într-o coloană rezervată observaţiilor vor fi înregistrate toate informaţile ce pot ajuta la precizarea identificării sau a naturii secvenţelor. Poate fi cazul aici de a se putea face atribuirea la o anumită construcţie şi atribuirea acesteia unei anumite secvenţe şi în general toate elementele care sunt considerate utile pentru specialiştii care se ocupă cu studierea mobilerului.

La acest nivel al interpretării datelor, dispunem de o cronologie relativă a sit-ului, atât de precisă cât este posibil, dar care nu oferă decât rareori elemente de cronologie ábsolută. În acest moment, o încaclrare cronologică nu poate fi stabilită decât dacă sunt examinate nivelorile datate istoric (construirea unui edificiu care se ştie când a fost realizat), căci toate operaţile de până în acest moment nu au fost efectuate pe baza elementelor cronologice furnizate de către mobilier. Aceasta nu este încă decât o modalitate de a garanta valabilitatea studiului care într-o primă fază nu se bazează decât pe exploatarea la maximum a datelor stratigrafice care are semnificaţia utilizării unui sistem paralel şi independent cu acela at înregistrării şi studierii mobilierului. Aceasta creează posibilitatea scăpării de sub pericolul redutabilului raţionament circular care constă din datarea unităţilor stratigrafice cu ajutorul mobilierului şi invers din datarea acestuia cu ajutorul unităţilor stratigrafice. Aceasta deoarece daç̆ elemenrele de cronologie absolută determinate de stratigtalie sunt rare, mobilierul în schimb furnizează datări ce adesta pot fi imprecise sau eronate. În consecinţă acest tip de datări trebuie să fie folosit cu cea mai mare prudenţă, pentru a nu fi tentaţi, utilizându-le în analiza stratigrafică, să fim influegţaţi de ele.

În acest timp , odată stabilită cu maximum de siguranţă posibllă cronologia relativă, trebuie incluse datările propuse de mobilier. După caz şi în funcţie de complexitatea sitului, se poate proceda într-o manieră uşor diferită pentru a se putea lămuri studiul stratigrafic prin intermediul datelor oferite de către mobilier. În cazul unui sit dens ocupat, care prezintă o organizare spaţială şi stratigrafică complexă și care deci oferă o multitudine de secvenţe ocupaţionale, cu un material abundent, vom avea nevoie de datări precise pentu a putea evalua durata în timp a fiecăreia dintre ele. În acest scop, se poate face apel la materialul arheologic pentru a se putea găsi eventual, adalogil sau informaţii etnografice pentru a se putea defini cât mai exact cu putinţă tipurile ocupaţionale (nivel social, tipul de ocupaţie:domestic sau industrial etc.) şi funcţia fiecărui spaţiu amenajat (bucătărie, dormitor, depozit). În acestă situaţie este necesară real|zarea unul studiu aprofundat al mobilierului din fiecare secvenţă, atât cronologic cât și tipologic. Un astfel de studiu poate fi realizat în acelaşi timp şi pentru a verifica precizia regrupării materialului în fiecare secvenţă. În cele mai multe din cazuri un studiu sumar al acestuia este suficient.

Pentru fiecare secvenţă este stabilită o fişă de sinteză care va fi completată de-a lungul operaţiilor amintite. Ea va purta numărul secvenţei, fazei şi perioadei, incluzând detaliat toate informaţiile stratigrafice permiţând stabilirea contextului, definirii tipului sit-ului căreia î aparţine, raporturile cu alte structuri şi cu alte secvenţe contemporane. După studiul mobilierului, această fişă va fi utilizată pentru notarea informaţiilor cronologice şi interpretările rezultate: din studiul materialului. Se pot, de exemplu, înregistra prezenţa ceramicii sau a altor obiecte, diversele procentaje ce permit evaluarea existentei unui depozit omogen sau nu, sau definirea depozitării unui material în poziţie secundară. Această evaluare este capitală în cazul studiulul mobilierului care nu prezintă caractere cronologice clare, cum este cazul aceluia osteologic, pentru care este adesea dificil dacă nu irnposibil de separat de acela rezidual. În consecinţă nu vom acorda aceeaşi importanţă oaselor ce provin dintro secvenţă ce conţine $70 \%$ ceramică reziduală cu acelea care provin dintr-o secvenţă care a furnizat 
un lot ceramic omogen. Î́n acest stadiu ceramica nu este utilizată decât pentru a preciza elemntele furnizate de studiul stratigrafic şi pentru a putea permite, eventual, precizarea cronologiei sitului. Astfel se va putea determina raportul (anterioritate/posterioritate) a structurilor care nu au relaţii stratiglafice.Aceste operaţii ca şi elaborarea notelor apoi valotificarea lor ulterioară pot fi facilitace de utilizarea informaticii.

Chiar dacă nu ne propunem să abordăm aici aspectele particulare legate de înregistrarea şi studierea mobilierului arheologic, trebuie să subliniem că această metodă de înregistrare și analiză stratigrafică a sit-urilor complexe a permis o mai bună cunoaştere a unui bun număr de tipuri de mobilier şi în particular a producţiei ceramice. Este în principal cazul unor serii de produse ceramice medievale glazurate din Val de Loire, atribuite în mad tradiţional secolului al- XIII- lea şi a cărei aparitie a putut fi datată în secolul al- XI- lea. A fost de asemeni posibil, dispunând de cronologii relativ fine, să se distingă evoluţtii tipologice şi tehnologice în cadrul unor ansambluri ceramice până atunci considerate drept omogene.

\section{Punerea în fază}

Odată în posesia tuturor elementelor care permit reconstituirea istoriei sitului, se poate încerca schiţarea unei viziuni mai sintetice a stratificării, efectuându-se punerea în fază.

Aceste secvenţe, care reprezintă fiecare un eveniment punctual din evolutia sit-uluii, pot fi regrupate. Astfel, operaţiile care sunt efectuate pentru construirea unei clădiri (tăierea pietrei, cernerea nisipului, prepararea mortarului și urmele lăsate de către lucrători: vetre temporare, colibe, etc), care sunt tot atâtea secvenţe, vor putea fi regrupate într-o singură fază care reprezintă construirea clădirii. În general, la nivelul fazei este posibilă stabilirea corelaţiilor dintre diferitele zone ale sit-ului sau ale săpăturii, corelaţii care nu pot fi stabilite la nivelul unităţilor stratigrafice.

Într-adevăr este imposibil, în cazul în care diferitele zone ale săpăturii sunt separate de către diferite obstacole (pereţi, martori de mari dimensiuni,etc.)să se obţină echivalente fiabile între unităţile stratigrafice, dar este posibil să se determine echivalerıţele între construirea sau ocısparea cutărei sau cutărei structuri.

Abia odată cu punerea în fază ne putem propune obţinerea unei imagini globale a sit-ului şi să încercăm evaluarea eventualejor lacune ale informației stratigrafice. O structură construită, prezentă într-un punct al asezării şi care a funcţionat după distrugerea uneia şi înainte de construirea alteia, poate să lase urme doar în anumite zone ale aşezării. Oricum, ea a avut o existenţă care se concretizează în nu puţine situaţii doar printr-un interstrat, aflat după distrugerea precedentului şi înainte de construirea ulteriorului. În situaţia în care acest strat nu are o existenţă concretă (tangibilă), el păstrează o importanţă oarecare pentru înţelegerea evoluţiei sit-ului şi trebuile să ţinem cont în general de ceea ce a fost distrus sau care nu a existat niciodată, deoarece acestea, (absenta/prezenta) pot marca perioade de abandon mai lung sau mai scurt, total sau parţal al sit-ului.

Neglijarea acestor hiatus-uri prezintă pericolul introducerii în studiu a runor distorsiuni importante. Un bun exemplu este dat de studiul ceramicii. În cursul stabiliriii secventei cronologice a ceramicii dintr-un sit, care poate servi drept referinţă pentru alte sit-uri, este foarte importantă continuitatea mobilierului, care poate exista între ceramica din prima constructie şi cea de a doua, chiar dacă nu putem preciza evoluţia acestora în timp. 
Determinarea fazelor, care este în sine procesul de reconstituire a istoriei sit-ului se face în mod invers fată de determinarea secvenţelor, de jos în sus, urmând ordineà depunerii, fiind acompaniată de note complete asupra evoluţiei sit-ului. Ele sunt destinate să faciliteze accesul la fişele de prelocrare a datelor stratigrafice. $O$ a doua diagramă este realizată de data acesta pe baza secvenţelor şi a relaţilor lor stratigrafice, evidenţiindu-se gruparea secvenţelor pe faze şi acestea în cadrul perioadelor. La acest nivel al demersului pot fi utilizate informaţile ce pot fi oferite de către sursele istorice (documente, texte sau ipoteze pe care le putem enunta ca urmare a analizei contextuale a sit-ului. Aceasta se poate întreprinde în mod particular în cazul unui oraş supus unei analize arheologice şi în cadrul căruia fiecare punct (sit) de pe teritoriul său are drept scop lămurirea unor aspecte particulare a evoluţiei urbar:e a orasului respectiv.

\section{Puoerea în perioadă}

Ultima operaţie care rămâne de îndeplinit, vizează facilitarea apropierilor dintre mai multe sit-uri dintr-un acelaşi cartier sau asupra unui acelaşi aspect al evoluţiei comunităţi respective.

Această constă din determinarea diverselor perioade istorice ale sit-ului. Am văzut că diferitele unităţi stratigrafice depuse în cursul construirii unui clădiri pot fi grupate în secvenţe care reprezintă fiecare o operaţie efectuată în cursul lucrărilor. Toate acestea pot fi regrupate pentru a reconstitui fazele construirii clădirii iar la rândul lor, ca şi difentele faze de ocupare şi distrugere ale aceleiaşi clădiri, vor constitui o perioadă a istoriei sit-ului. Punerea în perioadă a totalităţii sit-ului, ca şi operaţiile precedente necesită realizarea unui index ce permite regăsirea cu uşurinţă a datelor stratigrafice brute.

Ajunşi în acest ponct al prezentării principiilor exploatării datelor stratigrafice, este util să recapitulăm diferitele etape ale demersului, al cărui scop este de a asigura fiabilitatea interpretării finale, teducând cu fiecare etapă (atât cât este posibil), riscul de eroare sau impreciziile.

Analiza chirurgicală a sit-ului, identificarea fiecărui micro-element al stratigrafiei, garantează încă de pe teren colectarea cât mai exhaustivă posibil a datelor (stratigrafice şi de mobilier). Prima etapă a exploatării acesłor informaţii, care este punerea în secveạ̧̦ă, permite determinarea fiecărei activităţi care a determinat formarea depozitului arheologic şi stabilirea ordinei cronologice. Cea de a doua etapæ, punerea în fază are drept scop definirea diferitelor tipuri de utilizare a sit-ului, în timp ce punerea în perioadă permite conexarea informaţiilor stratigrafice de marile structuri ale sit-ului, care sunt în principal locuirile succesive prezente pe sit.

Se poate obiecta că demersul astfel prezentat nu ate nimic original şi că el este urmat de marea majoritate a arheologilor, indiferent care este tipul de sit pe care îl cercetează. Nu este mai puţin adevărat că în cazul sit-urilor urbane sau al acelora care prezintă secvenţe ocupaţionale lungi în timp, studiul este complicat de marea masă de informaţi stratigrafice rezultate în unrma săpăturii. Dar, indiferent care ar fi modalitatea de săpare sau înregistrare ce este folosită în cazul acestor sit-uri, tot se acumulează o mare cantitate de informaţii. În această situţatie numai o tehnică de studiere şi înregistrare riguroasă poate permite un studiu fiabil şi mai ales conservarea informaţilor într-o manieră mai obiectivă care permite orice revenire, reordonare sau reinterpretare a informaţilor astfel 
înregistrate şi stocate. Acesta credem că este unul din avantajele cele mai evidente ele folosirii unui astfel de sistem pe lângă celelalte enumerate mai sus.

Sistemul prezentat procedează la analizarea celei mai mici unităti spre sinteza cea mai largă posibilă, de-a lungul a trei etape distincte care se constitue în acelaşi timp în căte o ocazie de a se verifica datele de bază şi coerenţa rationamentului.

Trebuie de asemenea să ne asigurăm că rezultatele pe care sperăm să le obţinem nu vor fi stabilite pe baze contestabile şi în principal că nu se bazează pe o utilizare abuzivă a datelor rezultate din studiul mobilieruhui. Datele cronologice pe care ni le furnizează în principal ceramica, sunt în cele mai multe din cazuri imprecise şi trebuie utilizate cu cea mai mare prudenţa. Acesta este raţionamentul pentru care detele oterite de către studiul mobilierului şi cele stratigrafice sunt înregistrate într-o manieră independentă. Pe de altă parte, este frecventă situaţia conform căreia, la capătul a diferite etape ale studiului, se pot preciza diferite evenimente istorice ale sit-ului, situatie în care este adeseori necesară reverirea asuña unor ipateze formulate ariterior. Este posibil, de exemplu, ca ceramica ce provine dintr-o nivelare să prezinte caracteristicile tipice ale uneia ocupaţionale. În atare situaţie este posibil să revenim, de-a lungul întregului lant al operaţiilor deja efectuate şi să modificăm raţionamentul în funcţie de noile date, fişele si index-urile realizate facilitând considerabil această operaţie. La fel, se poate explica prezenta aberantă a unor fragmente ceramice într-o anumită secvenţă sau alta.

În termenul exploatării datelor stratigrafice, cromologia relativă a fiecărui elemeft și interpretarea sa vor putea fi ıtilizate in vederea realizării studiului arheologic al mobilierului. Noi am subliniat deja că acest studiu necesită existența unei echipe specializate pe tipuri de mobilier. În aceste condiţii trebuie ca acastor spetialişti să li se furnizeze un ghid care să le permită cunoaşterea contextului în care a fost descoperit materialul pe care îl studiază. Facilitarea utilizării fişelor de punere în secvenţă se poate face prin intermediul redactării unor note sintetice pentru fiecare perioadă şi care la rândul lor pot fi completate de informaţii istorice şi tot în ele pot fi incluse diverse ipoteze.

Înainte de a încheia dorim să subliniem încă o dată că acest sistem de săpătură şi înregistrare este pentru prima dată utilizat într-un tell, în această parte a Europei. Aceasta presupune pentru viitor și anumite modificări, dacă vom ajunge la concluzia că ele sunt necesare

Credem că, de asemeni, trebuie subliniată evoluţia din ce în ce mai evidentă în arheologia contemporană în ultima jumătate de secol în cazül marilor sit-uri pluristratificate care, pentru a putea fi cercetate în condiţii optime, au nevoie de existenta unor colective mari şi mai ales pluridisciplinare. Aceasta permite - în principiu - specializarea în verferea stıdierii unor categorii de informaţii în domenii precis definite.

Această evoluţie s-a manifestat, şi există în arheologia românească, permiţând, nu de puţine ori, obţinerea unor rezultate excepţionale. Dar ceea ce dorim să sublinieru în schimb, este afirmaţa necesităţii existenţei unor specialişti care să poată să lucreze în domeniul lor, chiar în cadrul - eventual - a mai multor colective ide cercetare.

În final, credem că mai trebuie evidenţiată o altă problemă pe care o considerăm foarte importantă.

În principiile sale generale conceptgla ce a generat metoda şi apoi tehnica de săpătură, prezentată de noi şi aplicată la Hîrşova, sunt cunoscute arheologilor români. 
Dar perfecţionarea sistemelor de şăł̆tură şi în primul rând a acelora de înregistrare, cum este cazul celui pus în practică la Hîeşova ridică o serie de probleme ce au un caracter general şi care, în consecinţă, se pot transforma - previzibil - în reale dificultăţi. Dintre acestea amintim doar una.

Dacă în general, reflexia şi rigoarea pot fi dobåndite ţi deci practicate pe şantierul arheologic sau în cabinetul de studiu, materializarea lor la un nivel corespunzător nu se poate face decât în anumite condiţ̧ii. Acestea constau, conform opiniei noastre în faptul că 0 astfel de săpătură şi înregistrare impune existenţa pe şantierele arheologice a unor lucrători calificaţi, capabili să execute un minim de operaţiuni de bază, profesionale.

Soluţia, de moment, adoptată de către noi, constă în colaborarea cu studenţii ce doresc să se formeze în acest domeniu. Dar este evident că ea nu poate fi generalizată din motive mult prea evidente pentru a le mai aminti măcar aici.

Oricum aceste probleme vor trebui săşi găsească o rezolvare determinată, în principal, de evoluţia previzibilă din punct de vedere economic a societăţi (în principal accelerarea marilor lucrări de investiţii) dar şi, nu mai puţin, a chiar arheologiei româneşti. 


\section{Bibliografie}

Barker, 1977

Biddle, 1972

Biddle, 1975

Biddle, Kjolbye-Biddle 1969

Bonora, 1979

Boüard, 1975

Carandioi, 1981

Courbin, 1963

Doe, 1975

Ferdiere, 1980

Galinie, 1980

Harris, 1975

Harris, 1977

Harris 1979 a

Harris 1979 b

Hudson, 1979

Jefferies, 1977

Lattes, 1986 a
Barker (P.), Techniques of Archeological Excavations, Londres, 1977, 286 p.

Biddle (M.), Excavations at Winchester $1970,9^{\text {th }}$ interim report. The Antiquaries Journa/L 1, 1972, 94-131.

Biddle (M.), Excavations at Winchester $1971,10^{\text {th }}$ and final report, The Antiquaries JournalLV 2, 1975, 96-337.

Biddle (M.), Kjolbye-Biddle (B.), Meters, areas and robbing, World Archaeology I 2, 1969, 208-219.

Bonora (F.), Nota su un'archeologia dell'edilizia, Archeologia Medievale, VI, 1979, 171-182.

Boüard (M. de), Manuel d'Archéologie médiévale, Paris, 1975, 340 p.

Carandini (A.), Storie della terra, manuale dello scavo archeologico, Bari, 1981.

Courbin (P.), Stratigraphie et stratigraphie: méthode et perspectives. Études archéologiques sous la direction de P. Courbin, Paris, 1963, 59-102.

Department of the Environment - Principles of publication in Rescue Archaeology. H.M.S.O. Londres, 1975.

Ferdière (A.), La fouille, pour quoi faire?, in SCHNAPP A., 1980, L'Archéologie aujourd'hui, Paris, Hachette, 1980, 23-60.

Galinié (H.), De la stratigraphie à la chronologie, in SCHNAPP A., 1980, L'archéologie aujourd'hui, Paris, Hachette, 1980, 63-85.

Harris (E.C.), The stratigraphic sequence: a question of time. World Archaeology 7, 1975, 109-121.

Harris (E.C.), Units of archaeological stratification, Norwegian Archaeological Review 10, 1977, 84-106.

Harris (E.C.), Principles of archaeological stratigraphy, Academic Press, Londres, 1979.

Harris (E.C.), The laws of archaeological stratigraphy, World archaeology, 11, 1979, 111-117.

Hudson (P.), Contributio sulla documentazione dello scavo: problemi di publiazione e della formazione dell'archivio archeologico nell'esperienza inglese, Archaeologia Medievale, VI, 1979, 329-343.

Jefferies (J.S.), Excavation records, techniques in use by the Central Excavation Unit, Department of the Environment, H.M.S.O. Londres, 1977.

Bats (M.), Fiches (J.Li), Poupet (P.), Py (M.), Dossier régional, Lattes côté recherche, Les Nouvelles de l'archéologie, 25, 1986, 55-79. 
Metoda de săpătură şi înregistrares datelor stratigrafice: tell-ul neo-eneolitic de la Hírsova

Lattes, 1986 b

Maetzke, Pleszyska,

Tabacziynsky, 1981
Bats (M.), Bessac (J.C.), Chabal (L.), Chazelles (C.A. de), Fiches (J.L.), Poupet (P.), Py (M.), Enregistrer la fouille archéologique, le système élaboré pour le site de Lattes (Hérault), ARALO, Lattes, 1986, 56 p.

Maetzke (G.), Pleszyska (T.), Tabacziynsky (S.), Problems of inference based on stratigraphic sequences: a tentative model, Archeologia Polona, 20, 1981, 159-176.

Maetzke, Rysiewska, Tabacziynsky, Urbnaczyck, 1967

Maetzke (G.), Rysiewska (T.), Tabacziynsky (S.), Urbanaczyck (P.), Preblemi dell'analisi descrittiva nelle ricerche su siti archeologici pluristratificat, Archeologia medievale, IV, 1967, 7-46.

Randoin, 1976

Randoin (B.), Les clefs du sol I, A propos d'archéologie urbaine à Tours, 2, Tours, LAU, 1976, 19-25.

Randoin, 1977 a

Randoin (B.), Les clefs du sol II, $A$ propos d'archéologie urbaine d Tours, 3, Tours, LAU, 1977, 10-15.

Randoin, 1977 b

Randoin (B.), Les clefs du sol III, $A$ propos d'archéologie urbaine à Tours, 4, Tours, LAU, 1977, 9-15.

Randoin, 1987

Randoin (B.), éd., Enregistrement des données de fouilles urbaines, Actes de table-ronde Tours 1987, Tours CNAU, 1987, 98 p.

Schnapp, 1980

Schofield, 1980

Schnapp (A.) dir., L'archéologie aujour'hui, Paris, Hachette, 1980, 320 p.

Schofield (J.), Site manual 1, the written record, Museum of London Department of urban archaeology, Londres, 1980.

Wheeler, 1954
Wheeler (Sir M.), Archaeology from the earth. Harmondsworth, 1954, Londres (Ici cité dans son édition Penguin 1968) 


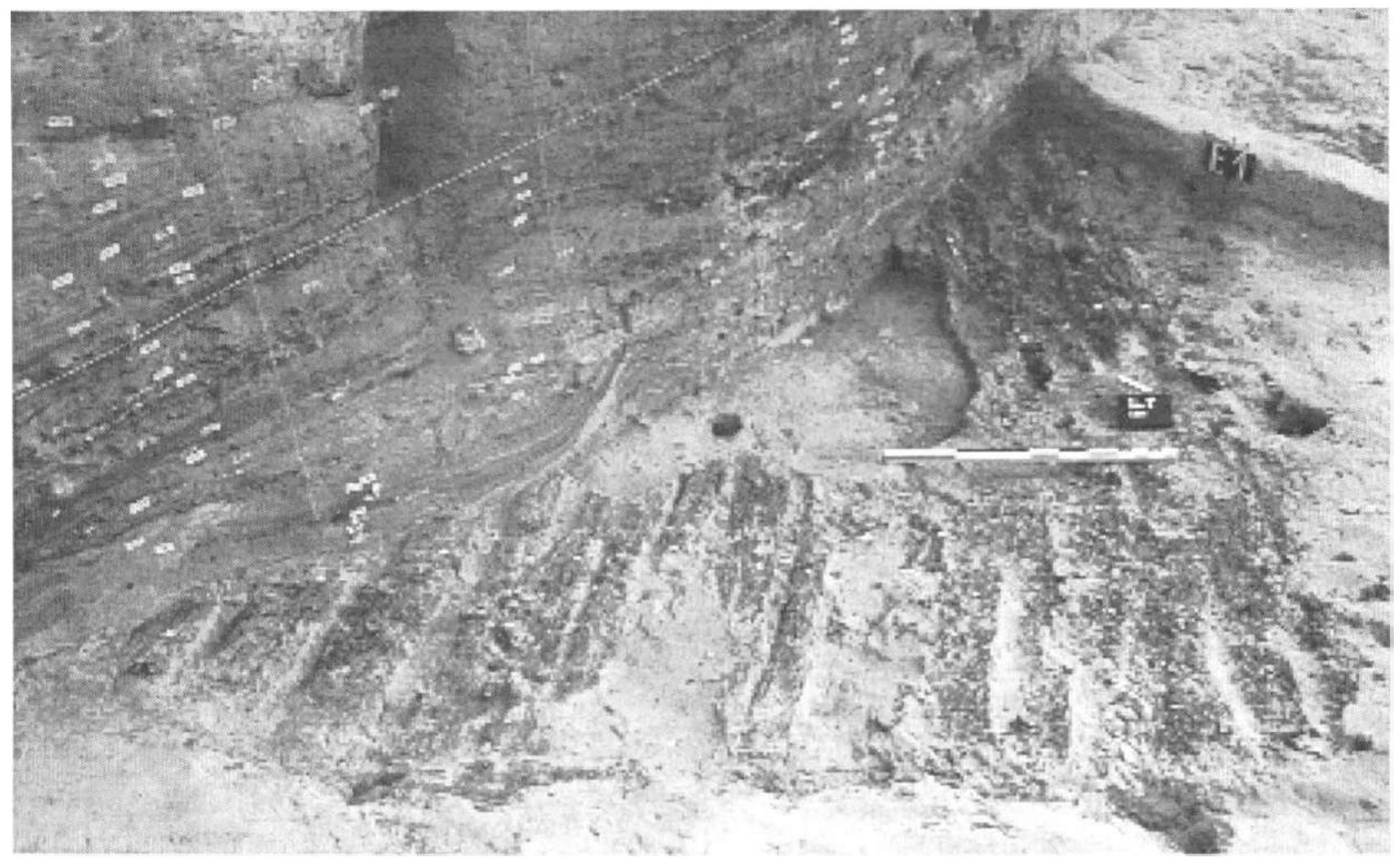

Hirscova-tell. C333. Structurä de lemn,

cu plan şi stratigrafierea u. S.urilor constructive şi ocupationale uzibile in profilul magistral

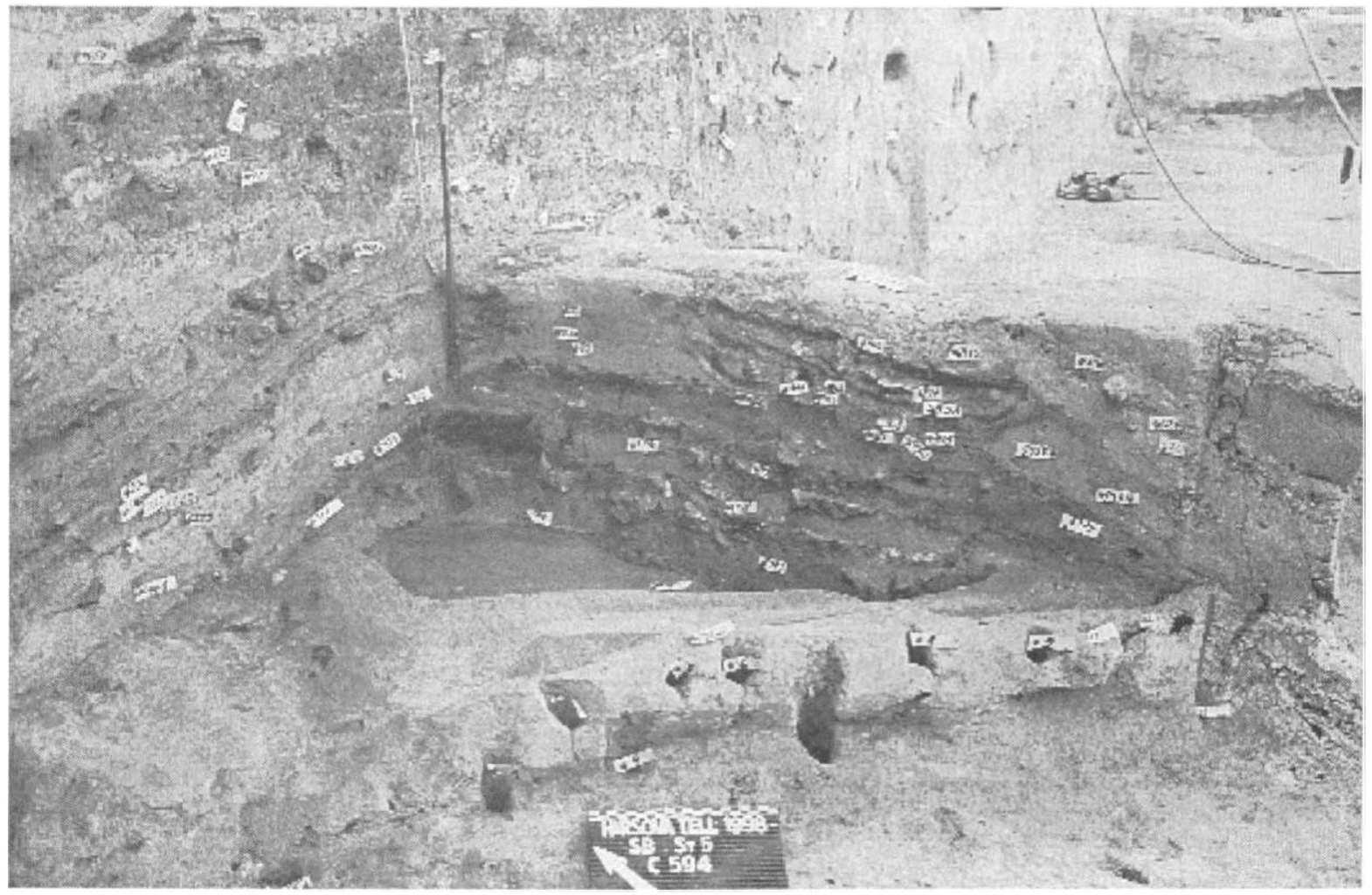

Hirsova tell. C594

Structură de constructie cu nulfiple retacer și detalii constructive surprinse în plan sîn protilul magistral 
Metoda de săpătură şi înregistrarea datelor stratigrafice: tell-ul neo-eneolitic de la Hîrsova

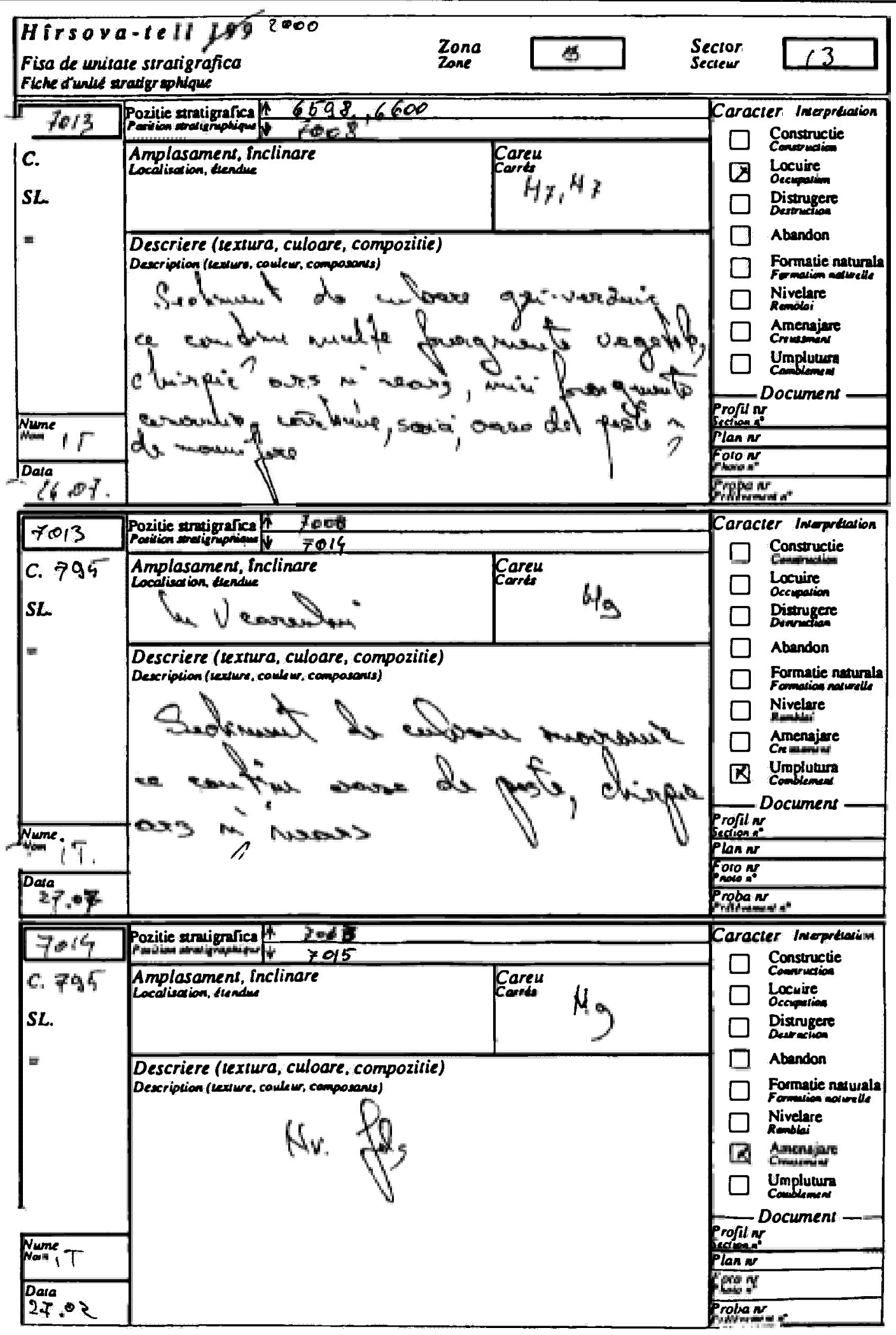

PI. II.a. Hinşava-tell. Fisła tip de înegistrane a unitattilor stratigrafice 

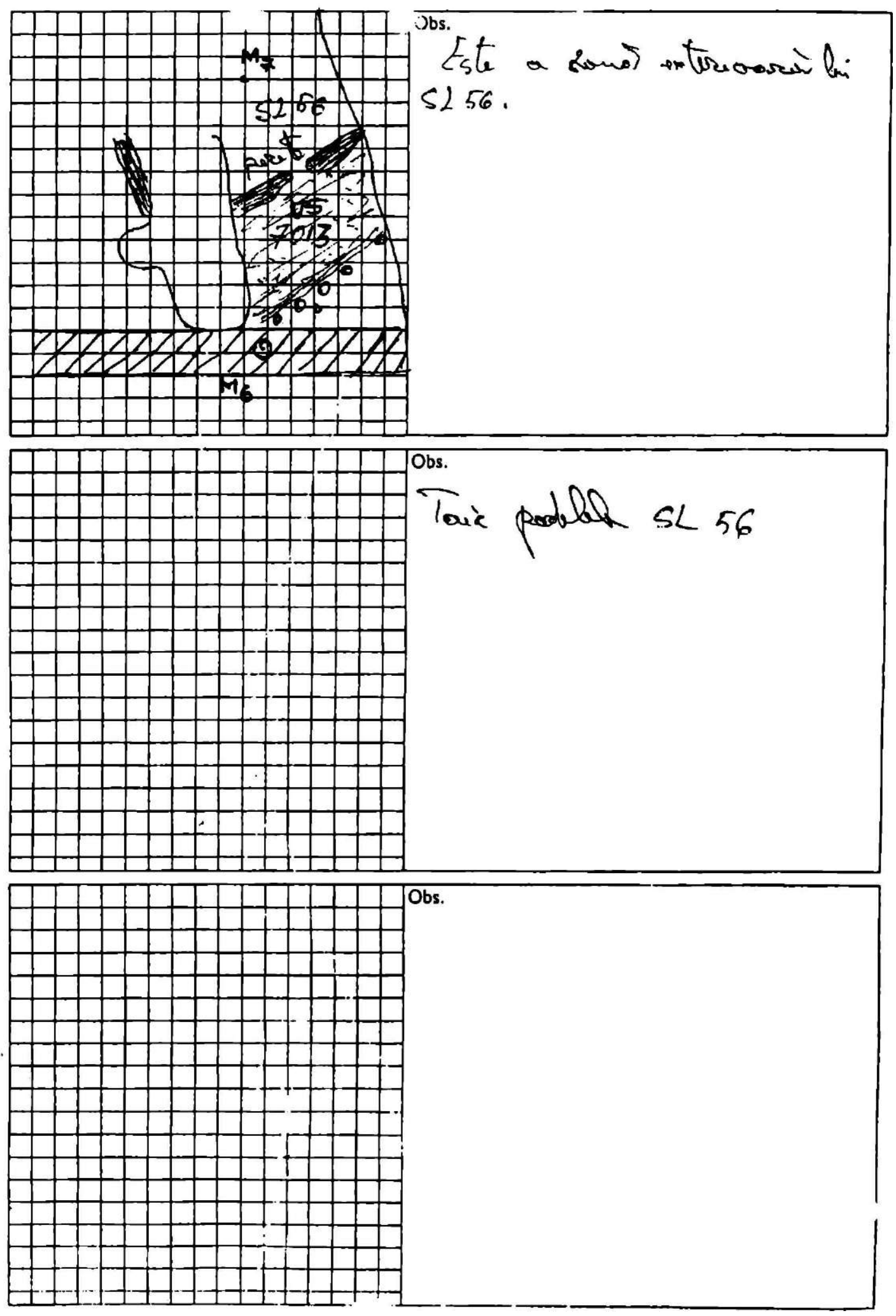

PI. II.b. Hirsova-tell. Fişă tip de îregistrare a unităfllor stratigrafice 
Metoda de săpătură şi înregistrarea datelor stratigrafice: tell-ul neo-eneolitic de la Hîrsova

IIIIIII1 19"3/1998

Fisa de complex

tons:

3

Car

$\pi$.

Sresur

8,9

$\mathrm{H}_{4} \mathrm{H}_{5} \mathrm{I} / 4 \mathrm{~T}$

I'utifịc atratigrafier

Sumir de unity a istratigrafiec

$1008,1009,1010,1011,1012,1013,014,1015$

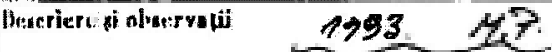

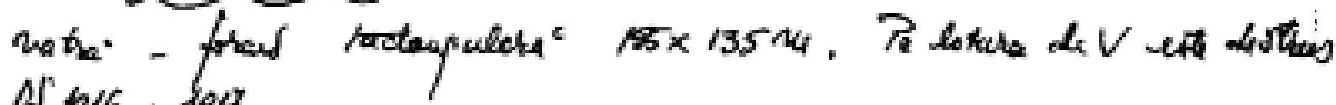
is $\Delta 5$ b16., hoif.

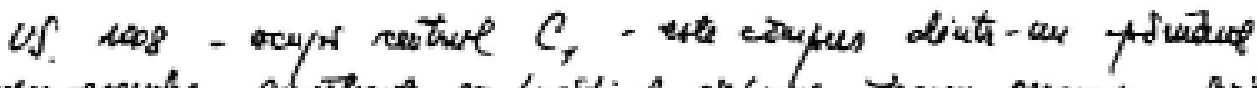

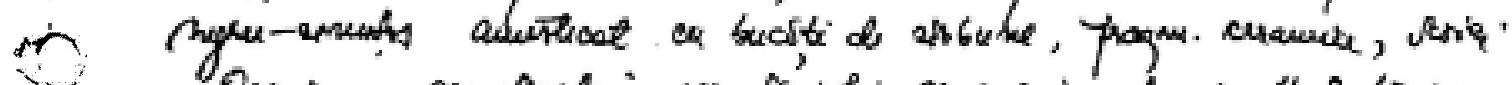

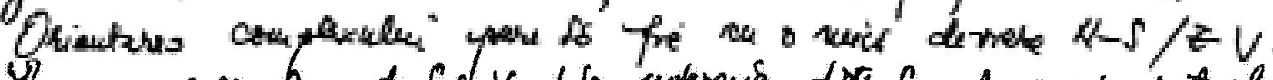

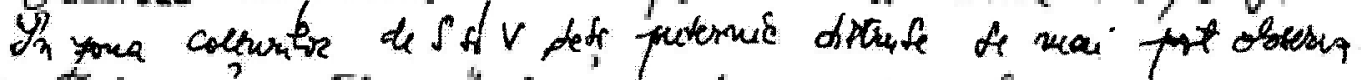

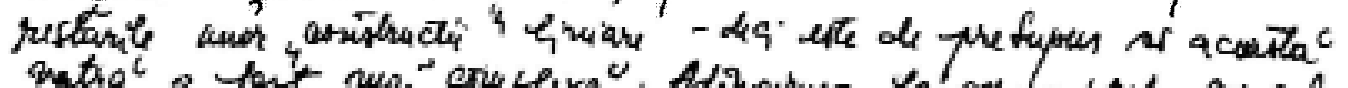

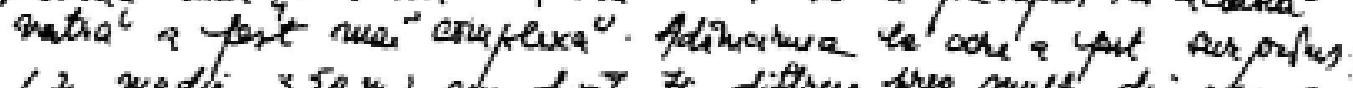

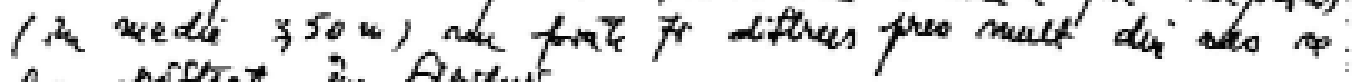
sa prittat in Aprturs.

$1998 \cdot 18$ תi⿱⺊口 V.V.

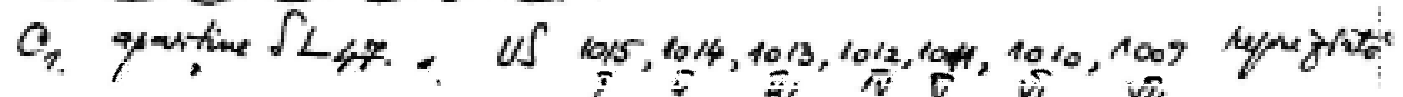

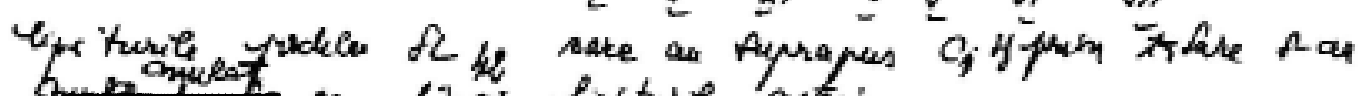

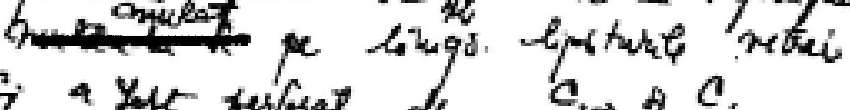

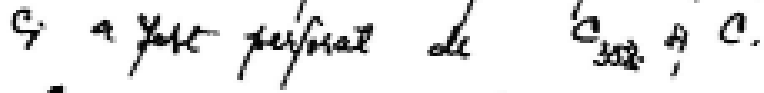

$2000-29$ iale $W$

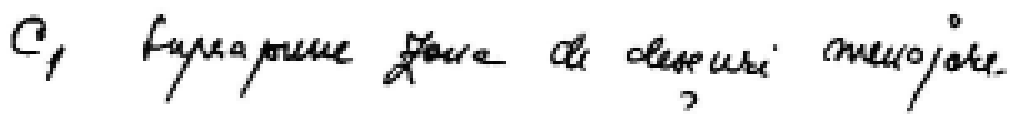

PI. III. Hîşova-tell. Fiğă tip de îregistrane a complexelor

229

www.mnir ro 


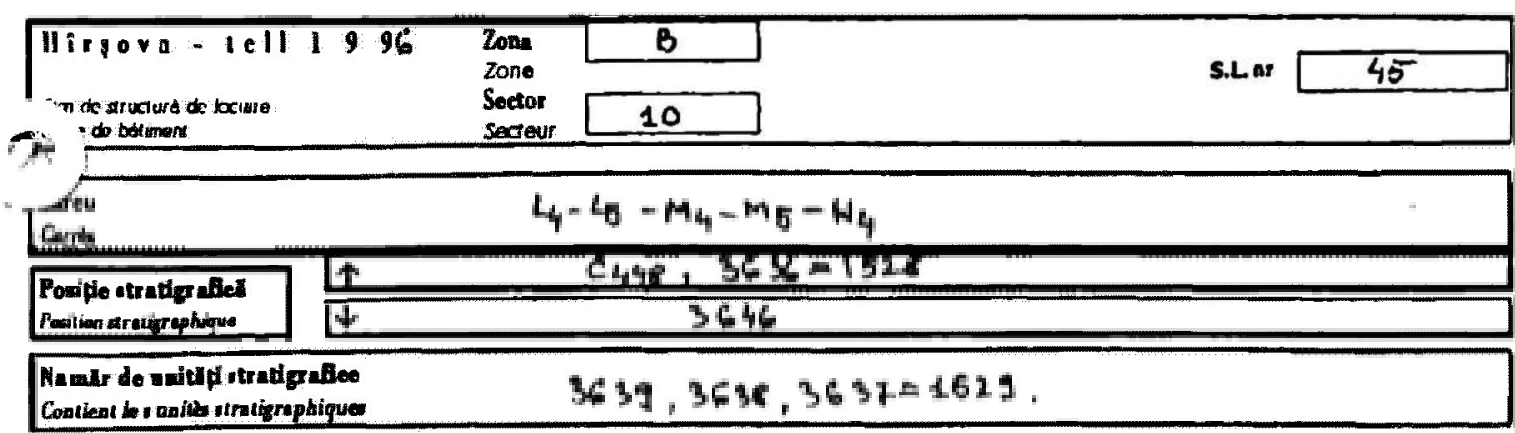

\section{Deseriere pi observafii}

Deseription et notes

Structurs de bewire partial anto (us $3637=1529$-elainpic

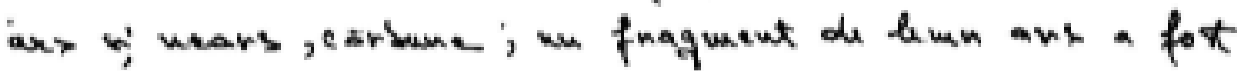

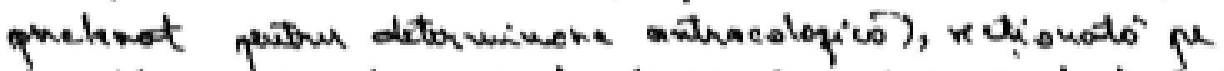

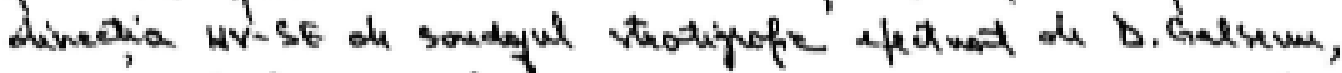

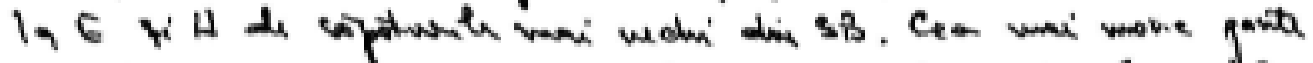

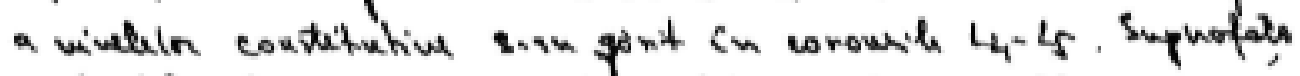

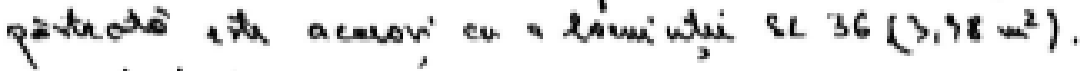

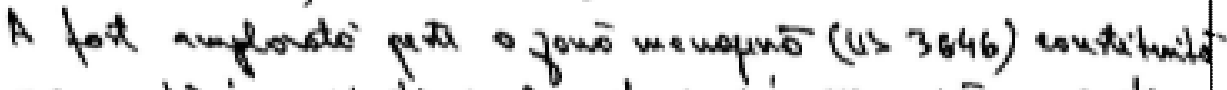

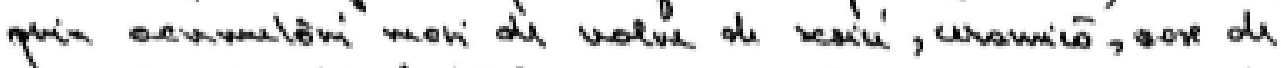

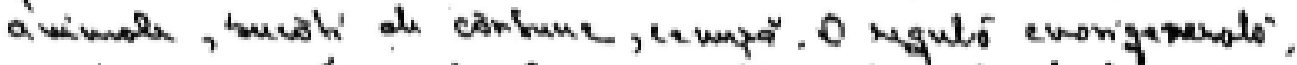

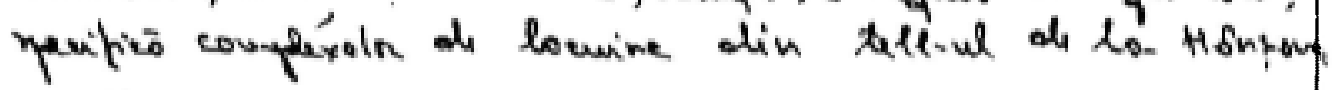

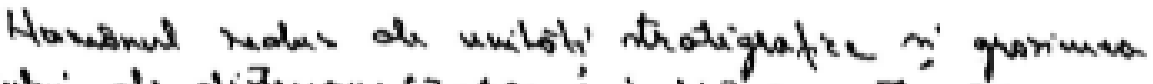

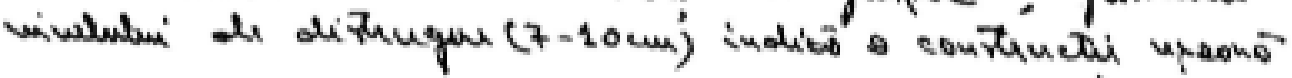

I us $3639(21534)$, podea din lat folme-miripos

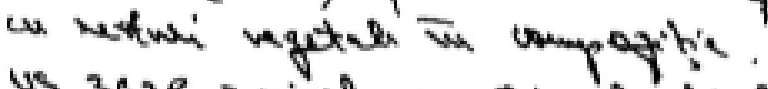

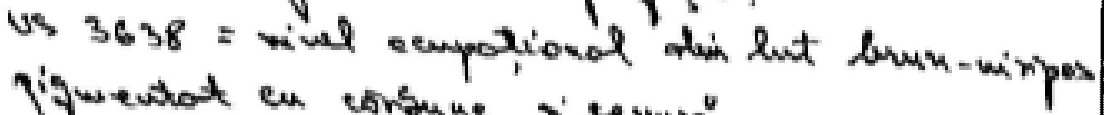

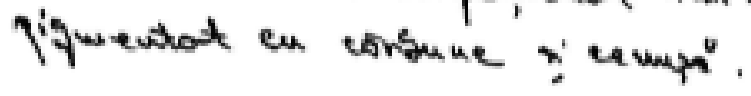

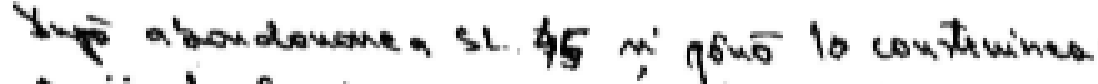

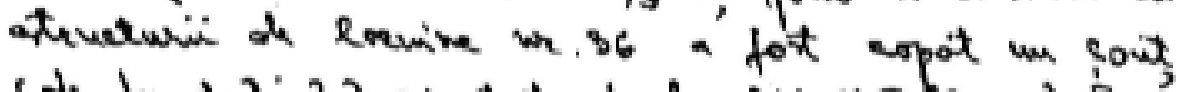

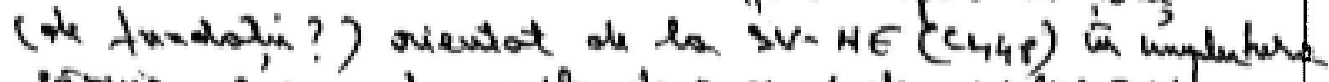

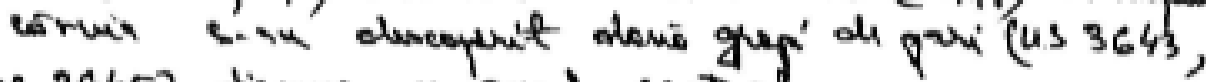

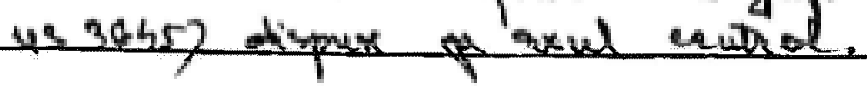

PI. IV. Hilşova-tell. Fişa tip de înregistrare a structuribr de locuire 


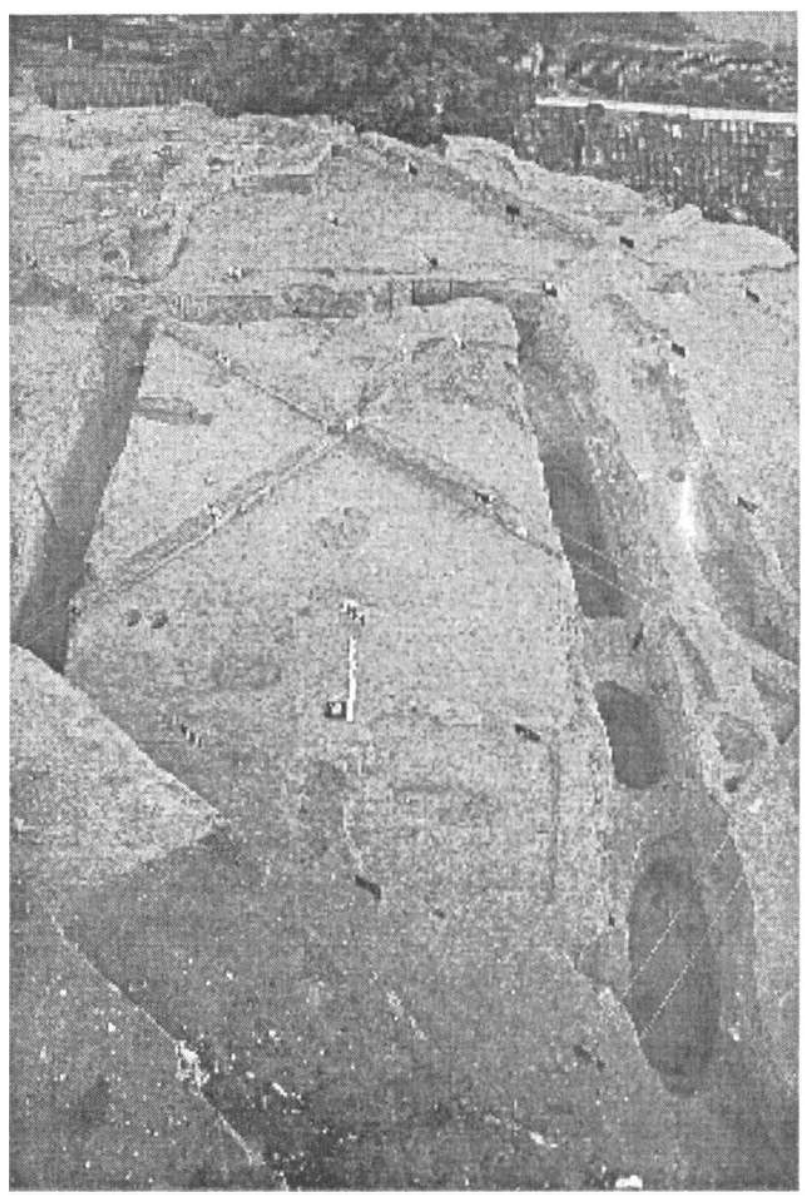

Hîs cova-tell. Santul de fundatie (C.98) al locuintei nr. 41.

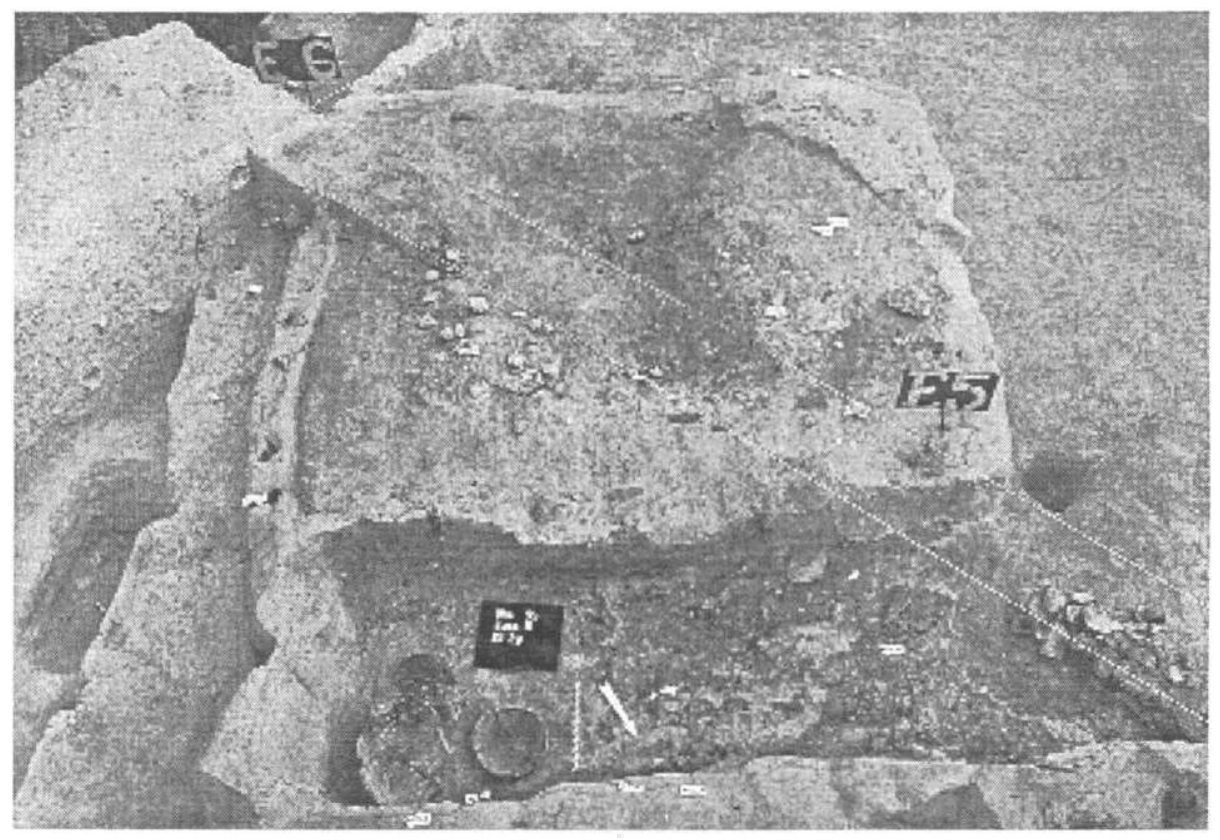

Hirşova-tell. Detaliu, locuința 29. Sunt viziblle perełil cu structura de rezisłenţă, cuptorul şi zona de depozitare a unor diverse oblecte intre acesta şi pereți locuinței. 


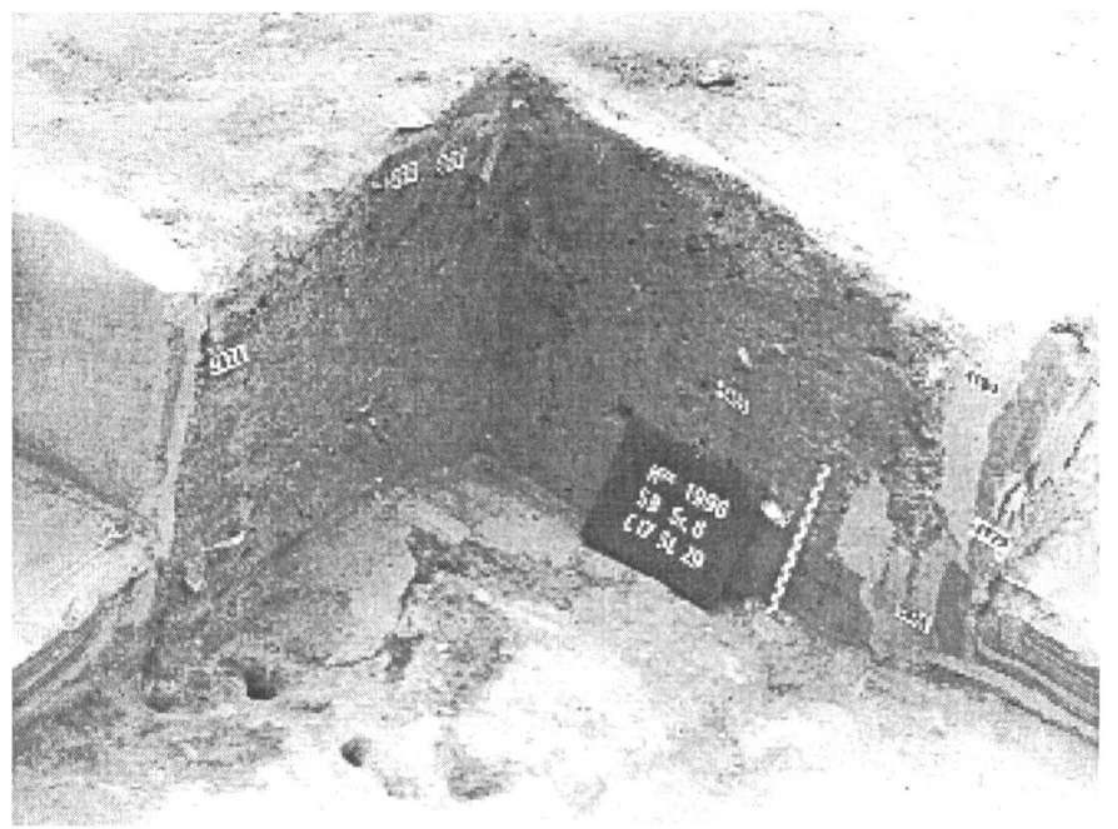

Hîrșova-tell. Detaliu. Secțiune a cuptorului S.L.29. Sunt vizibile fazele de construcție, refacere precum și nivelurile constructive și ocupaționale de podelele locuinței.

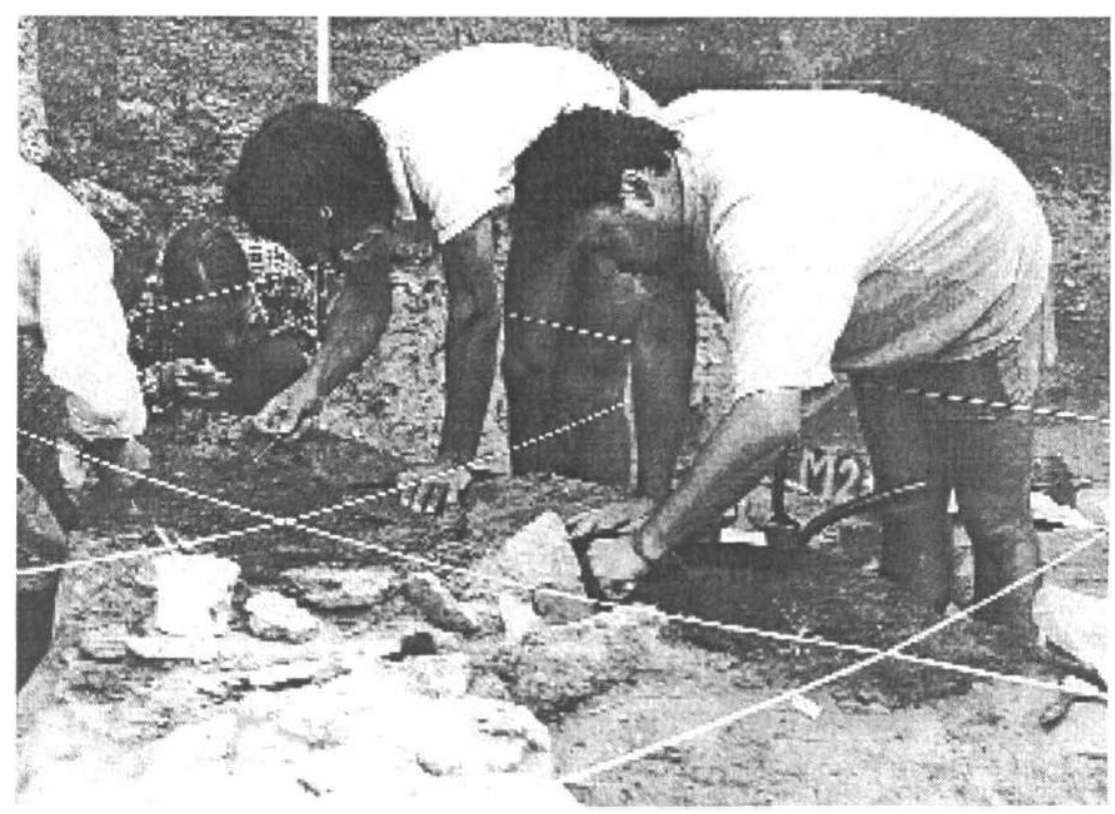

Hîşova-tell. Prelevări carpologice și antracologice de pe podeaua S.L.12. 


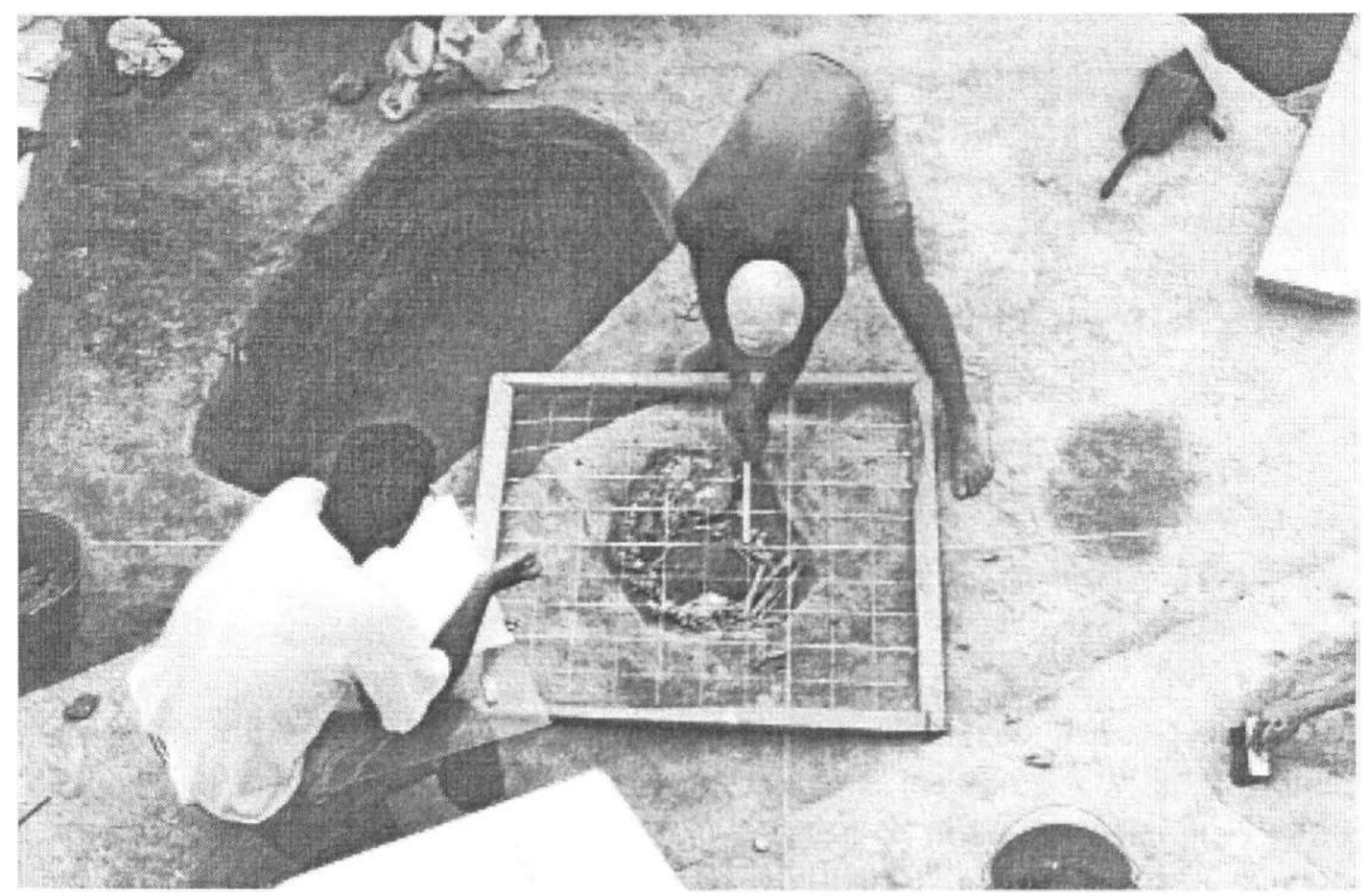

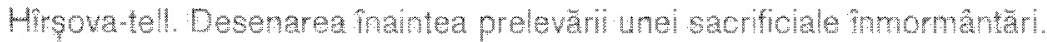

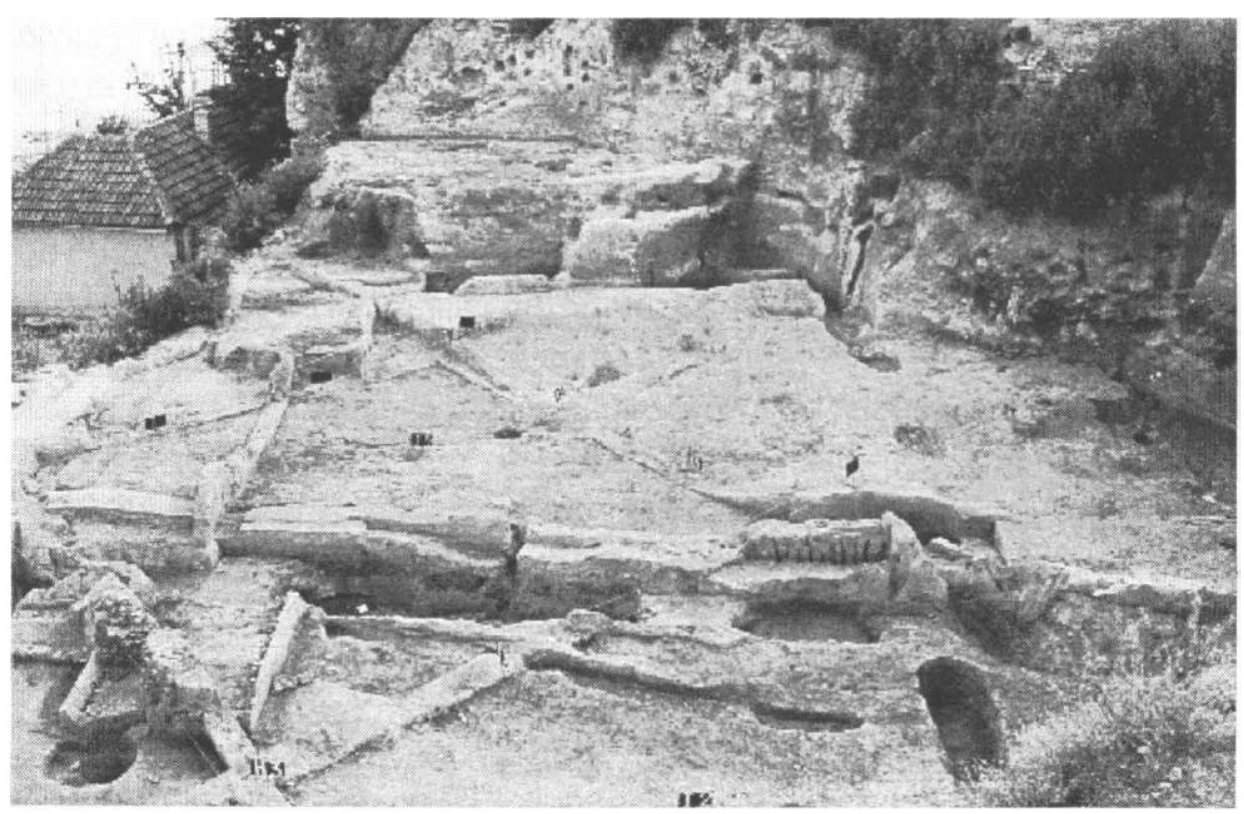

Hirșova. Vedere generală a S.L. 48 